\title{
Demersal bony fish of the outer shelf and upper slope of the southern Brazil Subtropical Convergence Ecosystem
}

\author{
Manuel Haimovici ${ }^{1}$, Agnaldo Silva Martins ${ }^{2}$, José Lima de Figueiredo ${ }^{3}$, \\ Pedro Castelli Vieira ${ }^{1}$
}

\footnotetext{
${ }^{1}$ Departamento de Oceanografia, Fundação Universidade do Rio Grande, Caixa Postal 474, $96201-900$ Rio Grande, RS, Brazil

${ }^{2}$ Curso de Pós-Graduaçào em Oceanografia Biológica, Fundação Universidade do Rio Grande, Caixa Postal 474, 96201-900 Rio Grande, RS, Brazil
}

${ }^{3}$ Museu de Zoologia da Universidade de São Paulo, Caixa Postal 7172, 01064-980 São Paulo, Brazil

\begin{abstract}
Ninety-three species of bony fishes were caught in 4 seasonal bottom-trawl surveys Carried out between July 1986 and May 1987 on the outer shelf and upper slope (124 to $587 \mathrm{~m}$ depth) along the southern Brazilian coast $\left(30^{\circ} 40^{\prime}\right.$ to $\left.34^{\circ} 30^{\prime} \mathrm{S}\right)$. On the outer shelf $(<179 \mathrm{~m})$, the demersalpelagic species Trichiurus lepturus, Trachurus lathami, Cynoscion guatucupa, Scomber japonicus, and Thyrsitops lepidopoides predominated and also to a lesser degree the demersal benthonic Umbrina canosai and Mullus argentinae. Antigonia capros and Priacanthus arenatus were found associated with the relic coral hard bottoms of the shelf break (180 to $249 \mathrm{~m}$ ). Further offshore, the demersal-pelagic species Ariomma bondi and Zenopsis conchifera and the demersal benthonic species Polyprion americanus and Helicolenus lahillei were abundant, both associated with rocky bottoms. The macrourids Coelorinchus marinii and Malacocephalus occidentalis characterized deep-water hauls (>450 $\mathrm{m}$ ). Frequent and widespread, but less abundant in the catch, were Polymixia lowei, Urophycis mystacea and Merluccius hubbsi. Mean total catch $\left(\mathrm{kg} \mathrm{h}^{-1}\right)$ decreased 6 -fold and the number of species by more than half along the depth range, with a sharp step at $350 \mathrm{~m}$. Both catch and number of species were slightly higher in the winter cruises. Most species occurred in both winter and summer-autumn cruises, but, with increasing depth, the relative abundance of species that occur year-round decreased, whereas fishes that occur mostly in winter increased. The catch of demersal-pelagic fish decreased sharply below $350 \mathrm{~m}$ and differed little among seasons; catches of demersal-benthonic fish were more evenly distributed across the depth range and were larger in winter and spring. The high number of species on the shelf break may be attributable to the higher variety of soft and consolidated substrates and the overlapping of different water masses along the water column. The north-south shift of the western boundary of the Subtropical Convergence appears to be mainly responsible for the seasonal changes in abundance of the species.
\end{abstract}

KEY WORDS: Subtropical Convergence - Teleost fauna - Distribution - Southern Brazil - Outer shelf Upper slope · Fish communities - Demersal survey

\section{INTRODUCTION}

During 1986 and 1987, 4 bottom trawl surveys on the external shelf and upper slope off southern Brazil were carried out from the RV 'Atlântico Sul' to assess the fishing potential of the area; this proved to be rather poor (Vooren et al. 1988, Haimovici \& Perez 1991a) but included more than 100 species, many of them commercially important in neighboring regions.
The marine fish fauna of the southwestern Atlantic, particularly the demersal fishes from the shelf break and the upper slope of the coast of southern Brazil, has scarcely been studied. Early Brazilian ichthyological surveys were conducted only to $200 \mathrm{~m}$ depth (Vazzoler 1975, Benvegnú-Lé 1978). In surveys performed by research vessels of other nations, e.g. RV 'Calypso' in 1961 (Roux 1973) and RV 'Walter Herwig' in 1966 (Yesaki 1973), only a few trawling stations were in our 
studied area. Thus, one of the objectives of this paper was to report the teleost fishes in the catches, their sizes and relative abundance over the depth range and the cruises and to provide some information about the life history of better-represented species in the survey. An analysis of trends in the relative abundance and number of species in relation to depth, temperature, latitude, and seasons of the year is also presented. Some comments on the general composition of the fish fauna of the region are included in the 'Discussion'.

As this deeper area is scarcely fished as compared to the continental shelf (Vooren et al. 1988, Haimovici et al. 1989b), its faunal composition is probably in an almost natural undisturbed state, therefore the present study is a good referential base for temporal comparisons or for comparisons with other regions sampled with equivalent gear.

\section{MATERIALS AND METHODS}

Samples were obtained in 4 groundfish survey cruises of the RV 'Atlântico Sul' in July 1986 (winter), September 1986 (late winter), March 1987 (late summer), and May 1987 (autumn) over the outer shelf and upper slope between Chui $\left(34^{\circ} 30^{\prime} \mathrm{S}\right)$ and Cape of Santa Marta Grande, Brazil (28 $\left.40^{\prime} \mathrm{S}\right)$. Each cruise covered approximately half of the area (Fig. 1).

Sixty-five fish samples were collected using a bottom trawl net with a $23.4 \mathrm{~m}$ footrope geared with $40 \mathrm{~cm}$ diameter steel bobbins and a $50 \mathrm{~mm}$ stretch-mesh cod end. The standard duration of the hauls was $60 \mathrm{~min}$ at a speed of 3.0 knots. After each haul bottom temperatures were recorded. All hauls were performed between dawn and dusk. Tow depth ranged from 124 to $587 \mathrm{~m}: 30 \%$ of the hauls were conducted between

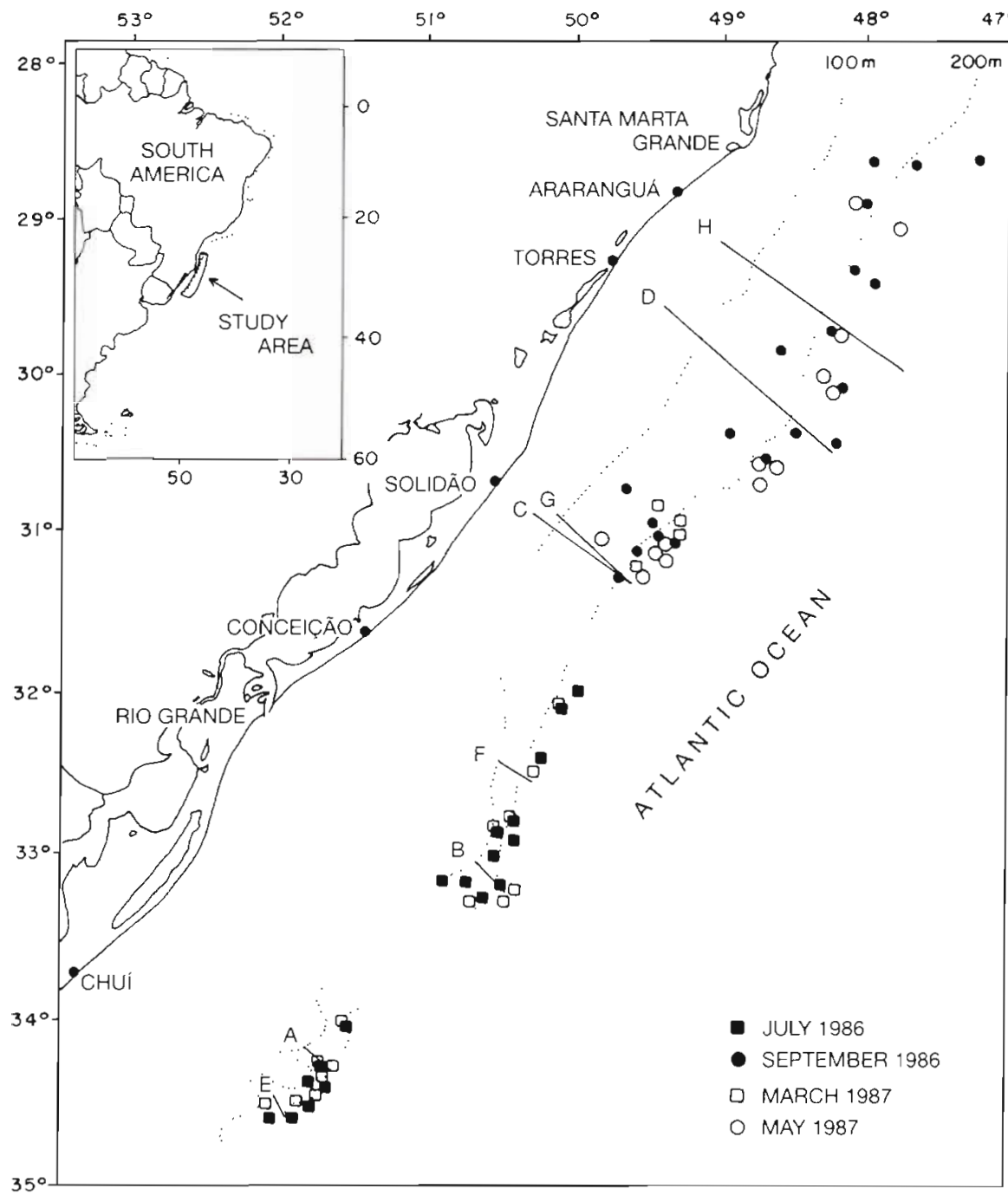

Fig. 1. Study area of the bottom trawl survey by the RV 'Atlântico Sul' off southern Brazil in 1986 and 1987. Empty and full circles and squares indicate fishing stations. Lines and letters indicate temperature profile transects
124 and $179 \mathrm{~m}, 21 \%$ between 180 and $249 \mathrm{~m}, 21 \%$ between 250 and $349 \mathrm{~m}, 12 \%$ between 350 and $449 \mathrm{~m}$ and $14 \%$ between 450 and $587 \mathrm{~m}$. Irregular hard bottoms are common in canyons in the shelf break, perpendicular to the coastline from Albardão to Rio Grande, and there are no extensive areas for trawling in the study area (see Vooren et al. 1988).

Temperature and salinity were measured with Nansen bottles at standard depths and along fixed transects at the beginning and end of each cruise and included in the survey final report by Castello (1991). When possible bottom temperature was recorded at the fishing stations. At depths over $200 \mathrm{~m}$ measurements were imprecise due to strong currents, and for some fishing stations, bottom temperatures were interpolated from transect and neighboring stations. Temperature profiles are shown in Fig. 2.

After each tow the fishes were classified, measured and weighed. For very large catches, a random subsample of $30 \mathrm{~kg}$ of the smaller fishes was classified. The number per hour, weight per hour and size composition of each species were calculated. 
Bony fishes were identified on board using the fish catalogs (identification guides) of Figueiredo \& Menezes (1978, 1980), Fischer (1978), Menezes \& Figueiredo $(1980,1985)$ and Menni et al. (1984).

The fishes were classified as 'demersal-benthonic', species that feed mostly on or near the bottom, or 'demersal-pelagic', that feed mainly in the water column (Angelescu \& Prenski 1987). Some mesopelagic species were also caught. The classification criterion was based on observation of the functional morphology, unpublished data on stomach contents and literature information on the species, genera or family.

For each cruise and depth range the total number and mean number of species per tow and the mean total catch (in $\mathrm{kg} \mathrm{h}^{-1}$ ) of demersal-benthonic, demersalpelagic and mesopelagic species were calculated. Several sources of bias are involved in abundance comparisons, as species and sizes are not equally accessible and vulnerable to bottom trawls. This is a limitation of the exploratory fishing survey method that must be borne in mind. A reciprocate correspondence analysis program [DECORANA described in Gauch (1982)] for the natural logarithm of the numerical abundance plus one $[\ln (x+1)]$ was run to investigate the distribution patterns of the bony fishes in winter and summer-autumn. Only species caught more than twice were included in the analysis.

\section{SURVEY AREA}

Bottom topography and morphology. The external shelf has a declivity of around $0.1^{\circ}$, becoming about $1^{\circ}$ in the upper slope. The shelf break is between 150 and $185 \mathrm{~m}$ and is not abrupt. Between Chui and Rio Grande $\left(34^{\circ} 20^{\prime}\right.$ to $\left.32^{\circ} 00^{\prime} \mathrm{S}\right)$ the shelf is 140 to $180 \mathrm{~km}$ wide, becoming narrower to the north, with a minimum of $90 \mathrm{~km}$ at the Cape of Santa Marta Grande $\left(28^{\circ} 40^{\prime} \mathrm{S}\right.$ ). The morphology and sediments of the continental shelf of Rio Grande do Sul were summarized by Martins et al. (1975). The inner shelf is dominated by sandy bottoms, but biodetrital shell banks exist parallel to the coast off Patos and Mirim lagoons. Sandy mud and

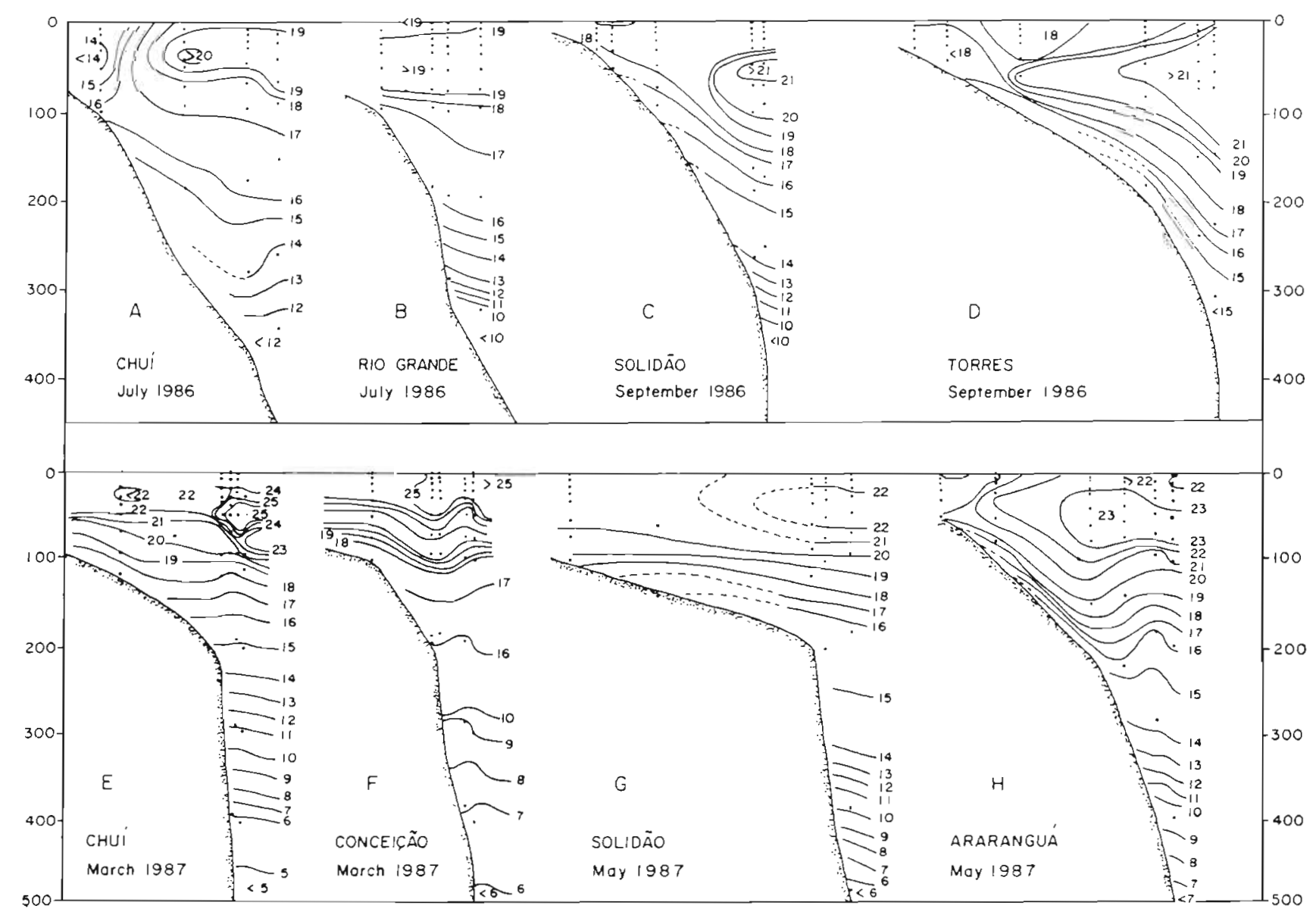

Fig. 2. Temperature profiles in the bottom trawl survey by the RV 'Atlântico Sul' off southern Brazil in 1986 and 1987 . Letters indicate the transects in Fig. 1 
muddy sand are dominant in the middle shelf, while mud rich in silts, clay and biodetrital sediments are found in the outer shelf. Relic coral hard bottoms are found along the shelf break. Mud is dominant in the slope but irregular hard bottoms are common in canyons perpendicular to the coast off Albardão $\left(33^{\circ} 20^{\prime} \mathrm{S}\right)$ and north of Rio Grande $\left(32^{\circ} 10^{\prime} \mathrm{S}\right)$.

Benthic and demersal macrofauna. The macroepibenthonic invertebrate fauna of the area was studied by Capitoli \& Bonilha (1991) and D'Incao \& Ruffino (1991). In the soft bottoms of the external shelf and upper slope of silty clay sediments the polychaetes Diopatra tridentata and Onuphis tenuis were common and the small crab Chasmocarcinus typicus was dominant. Skeletons and living hermatypic corals Cladocora debilis and Rhizopsammia manuelensis and gorgonians of the genus Primnoella were dominant on biodetrital sediments found extensively in the external shelf to the north of Rio Grande and all along the break of the slope. From 300 to $500 \mathrm{~m}$ patches of consolidate sedimentary rocks are common where the polychaete Eunice frauenfeldi and hermatypic corals were found. The more frequent and widespread macrocrustaceans were the demersal shrimps Peneaopsis serrata, Parapenaeus americanus and Parapandulus sp., the brachiurid crab Portunus spinicarpus and several anomurans of the genus Munida, the latter frequently preyed upon by several of the fish species sampled. In the outer shelf and break, the stomatopod Squilla brasiliensis and the small crabs Speocarcinus sp. and $C$. typicus were also common, and in deeper waters the large crab Chaceon notialis, this last species offering some fishing potential (Lima \& Lima 1991).

Thirty species of elasmobranch fish were collected in the same survey (Vooren 1991), and 24 of them were also found in shelf surveys. Among the most frequent were the sharks Galeorhinus galeus and Mustelus schmitti in winter, and 2 species of Squatina and Raja cyclophora year-round. Six species were found exclusively at depths $>400 \mathrm{~m}$.

Thirteen species of cephalopods were found in the area, most of the catch being represented by Loligo sanpaulensis and $L$. plei on the outer shelf, and Illex argentinus on the slope (Haimovici \& Perez 1991a). Benthic octopuses and sepioids are scarce in the region. (Haimovici \& Perez 1991b).

Hydrography. Several water masses can be identified over the external continental shelf and upper slope off southern Brazil (Emilsson 1961, Miranda et al. 1973, Castello \& Moller 1977, Hubold 1980a, b, Matsuura 1986). Tropical Water (TW) of the Brazil Current (temperature $>20^{\circ} \mathrm{C}$, salinity $>36.0 \mathrm{ppt}$ ) flows over the slope and, due to eddies and meander structures, occasionally reaches the continental shelf.
Subtropical Water (STW), also called South Atlantic Central Water, with temperatures ranging from 10 to $20^{\circ} \mathrm{C}$ and salinities from 34.3 to $35.9 \mathrm{ppt}$, is found below the Brazil Current. It results from the mixing of TW and Subantarctic Water (SAW) in the Subtropical Convergence zone, which fluctuates seasonally between 35 and $45^{\circ} \mathrm{S}$ (Legekis \& Gordon 1982, Olson et al. 1988). This water may upwell seasonally off northern Rio Grande do Sul, Santa Catarina and Cabo Frio or follow the meander-like pattern of the Brazil Current. SAW, derived from a coastal branch of the Malvinas/Falkland Current, extends up to $32^{\circ} \mathrm{S}$ but may reach further north in winter. Usually it penetrates beneath the Coastal Water between the 50 and $100 \mathrm{~m}$ isobaths. Its temperature off Chui is 10 to $12^{\circ} \mathrm{C}$ and can approach 14 to $16^{\circ} \mathrm{C}$ off Rio Grande; salinity ranges from 33.7 to $34.15 \mathrm{ppt}$. Along its eastern boundary a strong thermal gradient, classified by Miranda et al. (1973) as Slope Water, with intermediate temperature and salinity, separates it from the Brazil Current. Upwelling processes occur along the shelf break year-round but with higher intensity in summer (Lima 1992). Intermediate Antarctic Water (IAW) originating at the Antarctic Convergence may be recognized by its lower salinity at depths between 700 and $1100 \mathrm{~m}$ (Thomsen 1962). Along the continental slope this water may reach up to $400 \mathrm{~m}$ with salinities between 34.26 and $34.41 \mathrm{ppt}$ and temperature under $10^{\circ} \mathrm{C}$ in winter at the latitude of Rio Grande.

Bottom morphology contributes to explaining the behavior of the water masses: in winter, SAW of the inner branch of the Malvinas/Falkland Current penetrates onto the wide shelf from the south and reaches at most up to Conceição $\left(31^{\circ} 40^{\prime} \mathrm{S}\right)$. To the north the shelf is narrower and the influence of the Brazil Current is more evident, particularly in the warm seasons, while in the cold season STW may partially upwell on the shelf near the coast.

Temperature and salinity profiles at the beginning and end of each cruise showed that a mixture of SAW and STW dominated the external shelf and upper slope, and below it IAW was found (Fig. 2). Bottom temperature ranged from 16.6 to $19.0^{\circ} \mathrm{C}$ (at $100 \mathrm{~m}$ ) during winter and 14.0 to $16.0^{\circ} \mathrm{C}$ (at $200 \mathrm{~m}$ ) during summer-autumn surveys. Thermoclines were observed between TW and STW in the upper $200 \mathrm{~m}$ layer. Below $200 \mathrm{~m}$ depth, the measurement of temperature was imprecise, but temperature decreased gradually to under $10^{\circ} \mathrm{C}$ at $400 \mathrm{~m}$ and $6.2^{\circ} \mathrm{C}$ at $500 \mathrm{~m}$. Bottom temperature in July 1986 in the southern external part of shelf was found to be $2.5^{\circ} \mathrm{C}$ warmer than usual for the winter, probably due to a milder Malvinas/ Falkland Current influence in that year (Castello 1991). 


\section{RESULTS}

\section{Species composition}

The families, genera and species of teleost caught are listed in Table 1. A total of 93 species of 55 families and 86 genera were identified. The families with the highest numbers of species present were Serranidae (with 6 species) followed by Macrouridae (5), Myctophidae (4), Sciaenidae (4), Trichiuridae (4), Bothidae (3), Triglidae (3), Scorpaenidae (3), and Carangidae (3)

The frequency of occurrence, mean catch, mean weight, total length range, depth of catch and bottom temperature for each species are listed in Table 2. The relative abundance in different seasons (cruises) and depth ranges for individual species were calculated as percentage of the total catch in weight and included in Table 2 .

Mean weight ranged from $1 \mathrm{~g}$ for Maurolicus muelleri to $40 \mathrm{~kg}$ for Mola mola, both pelagic species. Among those species present in more than 3 tows, only Polyprion americanus had a mean weight over $9 \mathrm{~kg}$, and 3 species (Genypterus brasiliensis, Lophius gastrophysus and Priacanthus arenatus) over $1 \mathrm{~kg}$.

On the outer shelf, the demersal-pelagic species Trichiurus lepturus, Trachurus lathami, Cynoscion guatucupa, Scomber japonicus and Thyrsitops lepidopoides predominated and also to a lesser degree the demersal-benthonic species Umbrina canosai and Mullus argentinae; all of them were more abundant in shallower water Antigonia capros and Priacanthus arenatus were found associated with the relic coral hard bottoms of the shelf break. Further offshore, the abundant species were the demersal-pelagic Ariomma bondi and Zenopsis conchifera, and the demersalbenthic Polyprion americanus and Helicolenus lahillei, both associated with rocky bottoms, and Coelorinchus marinii and Malacocephalus occidentalis in deeper water. Widespread, but less abundant in the catch, were Polymixia lowei, Urophycis mystacea and Merluccius hubbsi.

Large ichthyophagous demersal bony fishes such as Epinephelus flavolimbatus, Lopholathilus villarii, Genypterus brasiliensis, Pseudopercis sp. and Lophius gastrophysus were rarely caught and did not occur in water deeper than $350 \mathrm{~m}$.

On the winter cruises, Polyprion americanus, Scomber japonicus, Trichiurus lepturus, Trachurus lathami, Umbrina canosai and Helicolenus lahillei were the most abundant teleosts. The most frequently occurring species on summer-autumn cruises were Cynoscion guatucupa, Antigonia capros and Priacanthus arenatus in the south and T. lathami, Thyrsitops lepidopoides, $T$. lepturus, $U$. canosai and Zenopsis conchifera in the north.
This survey yielded a number of species rarely caught or otherwise recorded for the first time in Brazilian waters: Dysomminia rugosa, Polymetme corythaeola, Stomias affinis, Melanostomias niger, Diaphus effulgens, Gymnoscopelus piabilis, Symbolophorus barnardi. Neocopelus macrolepidotus, Macruronus magellanicus, Benthocometes robustus, Malacocephalus laevis, Malacocephalus occidentalis, Ventrifossa ori, Beryx splendens, Xenolepidichtys dalgleishi, Prometichthys prometheus, Benthodesmus elongatus and Lepidopus sp. (see Nakamura \& Parin 1993 for species identity).

Additional information on the distribution, sizes and life history of some species follows.

Merluccius hubbsi. This hake is found from the coast of Rio de Janeiro State to the southern tip of South America (Angelescu \& Prenski 1987, Fagundes \& Gaelzer 1991). It was the most frequent teleost, occurring in 37 hauls but representing only $1.18 \%$ of total bony fishes caught (Table 2). This species was taken in a wide range of depths and bottom temperatures, from 120 to $490 \mathrm{~m}$ and from 6.8 to $17^{\circ} \mathrm{C}$. Total length ranged

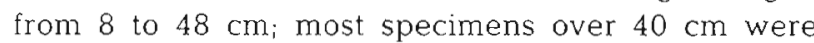
caught in the south and in winter (Fig. $3 \mathrm{~A}$ ), juveniles under $30 \mathrm{~cm}$ being more abundant between the 60 and $180 \mathrm{~m}$ isobaths. Mature females were found only in winter. On the shelf, juveniles fed mostly on zooplankton, and adults on fish (Engraulis anchoita, Trachurus lathami and $M$. hubbsi) and squid (Illex argentinus and Loligo sanpaulensis). Commercial catches of $M$. hubbsi are not common in the area and are restricted to the winter season (Haimovici et al 1989b). Recent studies show that the southern Brazilian coast is mainly a nursery ground for the same population unit that spawns in winter off Uruguay and northern Argentina (Haimovici et al. 1993).

Zenopsis conchifera. The buckler dory is a species widely distributed in the Atlantic Ocean. It occurred in 34 hauls, and its length ranged from 5 to $56 \mathrm{~cm}$. Larger specimens were more frequent in the 250 to $349 \mathrm{~m}$ range (Fig. 3B). Yesaki et al. (1976) suggested that there was some fishery potential for the buckler dory. but this did not appear evident with our gear; a midwater trawl would probably work out better. Females over $35 \mathrm{~cm}$ were found maturing in autumn and ripe in winter. $Z$. conchifera preys mainly on Maurolicus muelleri, Diaphus dumerilii and Euphausia similis. Macpherson (1983) found this species feeding mainly on fishes off South Africa.

Synagrops spinosus. Widely distributed in the western Atlantic Ocean, this small fish occurred in 33 hauls mainly in the southern portion of the survey area at depths greater than $350 \mathrm{~m}$. Undersampled because of its small size, but probably abundant in the region, it was caught in a wide range of depths and temperatures. It is commonly preyed upon by Pagrus pagrus 
Table 1 Teleost species caught in a bottom trawl survey off southern Brazil by the RV 'Atlàntico Sul' in 1986 and 1987 . Families are arranged in systematic order according to Nelson (1984)

\begin{tabular}{|c|c|}
\hline Species & Species \\
\hline Muraenidae & Triglidae \\
\hline Gymnothorax ocellatus Agassiz, 1831 & Bellator brachychir (Regan, 1914) \\
\hline Synaphobranchidae & Prionotus nudigula Ginsburg, 1950 \\
\hline Dysommina rugosa Ginsburg, 1951 & Prionotus punctatus (Bloch, 1797) \\
\hline Congridae & Polypronidae \\
\hline Conger orbignyanus Valenciennes, 1847 & Polyprion americanus (Schneıder, 1801) \\
\hline Engraulididae & Serranidae \\
\hline Engraulis anchoita Hubbs \& Marını, 1935 & Dules aunga Cuvier, 1829 \\
\hline Argentinidae & Epinephelus flavolimbatus Poey, 1865 \\
\hline Argentina striata Goode \& Bean, 1896 & Holanthias martinicensis (Guichenot, 1868) \\
\hline Stemoptychidae & Plkea rosa (Günther, 1880) \\
\hline Maurolicus muelleri (Gmelin, 1788) & Serranus atrobranchus (Cuvier, 1829) \\
\hline Phothichthyidae & Priacanthidae \\
\hline Polymetme corythaeola (Alcock, 1898) & Cookeolus japonicus (Cuvier, 1829) \\
\hline Stomidae & Priacanthus arenatus Cuvier, 1829 \\
\hline Stomias affinıs Günter, 1887 & Acropomatidae \\
\hline Melanostomiidae & Synagrops bellus (Goode \& Bean, 1896) \\
\hline Melanostomias niger Gilchrist \& von Bonde, 1924 & Synagrops spinosus (Schultz, 1940) \\
\hline Synodontidae & Branchiostegidae \\
\hline Saurida caribbaea Breder, 1927 & Caulolatilus chrysops (Valenciennes, 1833) \\
\hline Chlorophthalmidae & Lopholatilus villarii Ribeiro. 1915 \\
\hline Chlorophthalmus agassizi Bonaparte, 1840 & Pomalomidae \\
\hline Parasudis truculenta (Goode \& Bean, 1896) & Pomatomus saltatrix (Linnaeus, 1766) \\
\hline Neoscopelidae & Carangidae \\
\hline Neoscopelus macrolepidotus Johnson, 1863 & Decapterus tabl Berry, 1968 \\
\hline Myctophidae & Naucrates ductor (Linnaeus, 1758) \\
\hline Diaphus dumerili (Bleeker, 1856) & Trachurus lathami Nichols, 1920 \\
\hline Diaphus effulgens (Goode \& Bean, 1896) & Bramidae \\
\hline Gymnoscopelus piabilis (Whitley, 1931) & Brama brama Bonnaterre, 1788 \\
\hline Symbolophorus bamardi (Tåning, 1932) & Lutjanidae \\
\hline Bregmacerotıdae & Pristipomoides freemani Anderson, 1966 \\
\hline Bregmaceros atlanticus Goode \& Bean, 1886 & Sparidae \\
\hline Gadidae & Pagrus pagrus (Linnaeus, 1758) \\
\hline Urophycis brasihensis (Kaup, 1858) & Sciaenidae \\
\hline Urophycis mystacea Ribeiro, 1903 & Cynoscion guatucupa (Cuvier, 1830 ) \\
\hline Merluccidae & Cynoscion jamaicensis (Vaillant \& Bacourt, 1883) \\
\hline Merluccius hubbsi Marinı, 1933 & Micropogonias furnieri (Desmasrest, 1823) \\
\hline Macruronus magellanicus Lonnberg, 1907 & Umbrina canosai Berg. 1895 \\
\hline Macrouridae & Mullidae \\
\hline Coelorinchus marinii Hubbs, 1934 & Mullus argentinae Hubbs \& Marini, 1935 \\
\hline Malacocephalus laevis (Lowe, 1843 ) & Cheilodactulydae \\
\hline Malacocephalus occidentalis Goode \& Bean, 1885 & Sclaenoides bergi Noman, 1937 \\
\hline Ventrifossa orj (Smith, 1968) & Percophidae \\
\hline Ophidiidae & Bembrops heterurus (Ribe1ro, 1903) \\
\hline Benthocometes robustus (Goode \& Bean, 1886) & Percophis brasiliensis Quoy \& Gaimard, 1824 \\
\hline Genypterus brasiliensis (Regan, 1903) & Pinguipedidae \\
\hline Batrachoididae & Pseudopercis spp. \\
\hline Porichthys porosissimus (Valenciennes, 1837) & Callionymidae \\
\hline Lophiidae & Synchiropus agassizu (Goode \& Bean, 1888) \\
\hline Lophius gastrophysus Ribeiro, 1915 & Gempylidae \\
\hline Trachichthyidae & Prometichthys prometheus (Cuvier, 1832) \\
\hline Hoplostethus occidentalıs Woods, 1973 & Thyrsitops lepidopoides (Cuvier, 1831) \\
\hline Berycidae & Trichiuridae \\
\hline Beryx splendens Lowe, 1.834 & Benthodesmus elongatus (Clarke, 1879) \\
\hline Polymixnidae & Evoxymetopon taeniatus Poey, 1863 \\
\hline Polymixia lowei Günter, 1859 & Lepidopus sp. (see Nakamura \& Parin 1993) \\
\hline Zeidae & Trschiurus lepturus Linnaeus, 1758 \\
\hline Zenopsis conchifera (Lowe, 1850) & Scombridae \\
\hline Grammicolepididae & Auxis thazard (Lacepede, 1800) \\
\hline Xenolepidichthys dalgleishi Gilchnst, 1922 & Sarda sarda (Bloch, 1793) \\
\hline Caproidae & Scomber japonicus Houttuyn, 1782 \\
\hline Antigonia capros Lowe, 1843 & Centrolophidae \\
\hline Macroramphosidae & Centrolophus sp. \\
\hline Macroramphosus scolopax (Linnaeus, 1758) & Ariommatidae \\
\hline Notopogon fernandezianus (Delfin, 1899) & Ariomma bond 1 Fowler, 1930 \\
\hline Dactylopteridae & Stromateidae \\
\hline Dactylopterus volitans (Linnaeus, 1758 ) & Peprilus paru (Linnaeus, 1758) \\
\hline Scorpaenidae & Bothidae \\
\hline Helicolenus lahillei Norman, 1937 & Cithanchthys cornutus (Günther, 1880 ) \\
\hline Pontrnus rathbuni Goode \& Bean, 1896 & Etropus longimanus Norman. 1933 \\
\hline Setarches guenthen Johnson, 1862 & Paralichthys isosceles Jordan, 1890 \\
\hline Peristedirdae & Paralichthys patagonicus Jordan. 1889 \\
\hline Peristedion altipınne Regan, 1903 & Molidae \\
\hline Peristedion $\mathrm{sp}$ & Mola mola (Linnaeus, 1758) \\
\hline
\end{tabular}




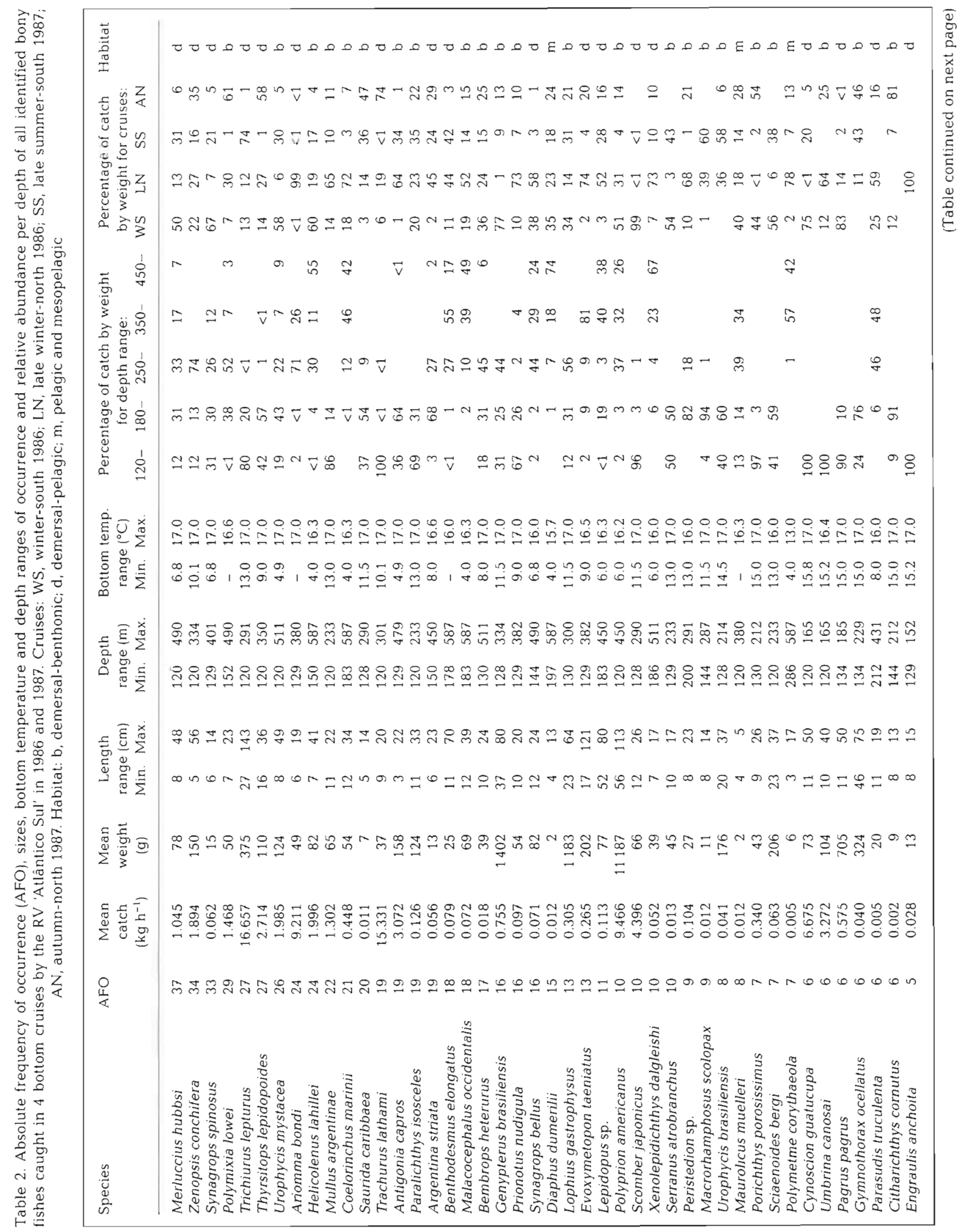




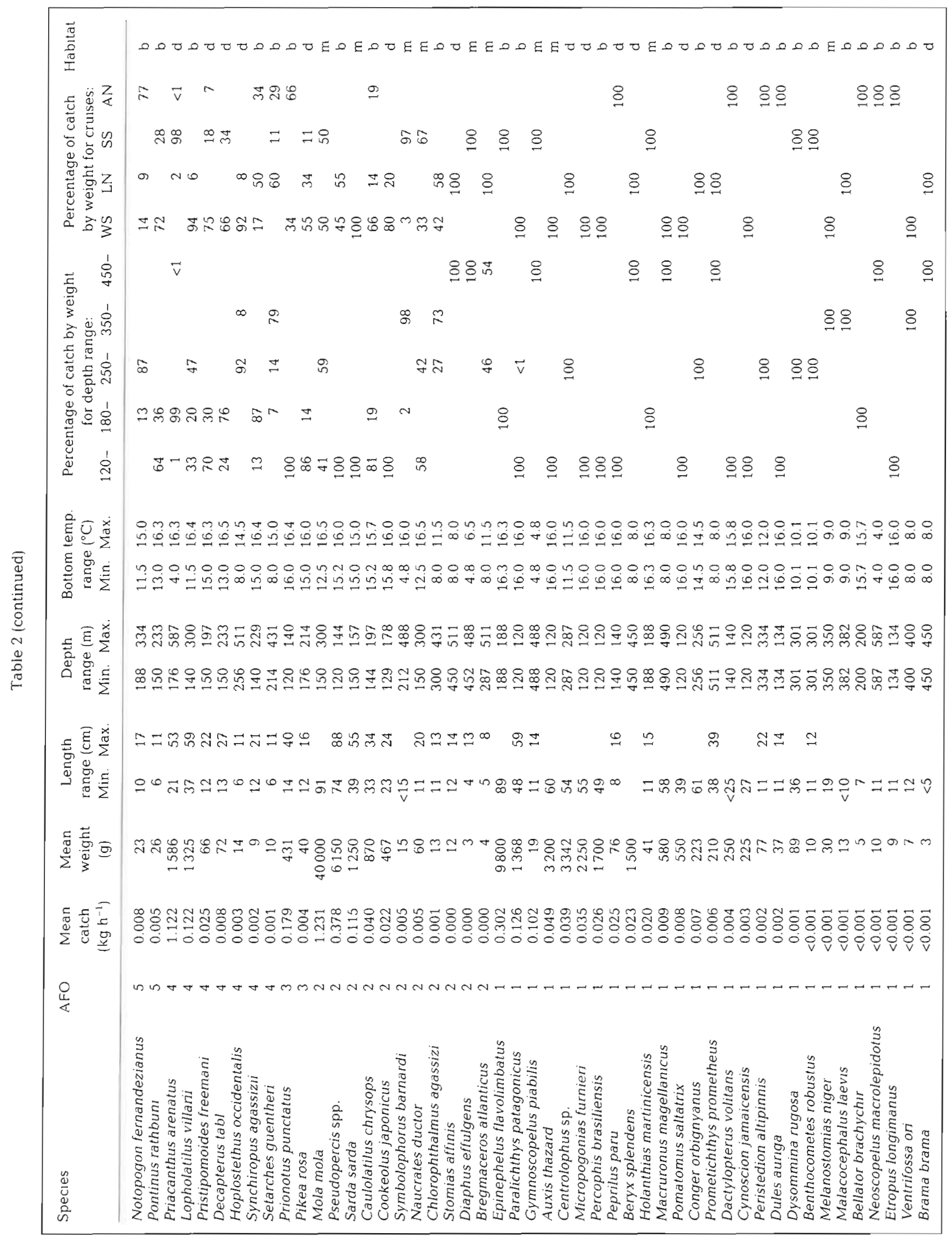



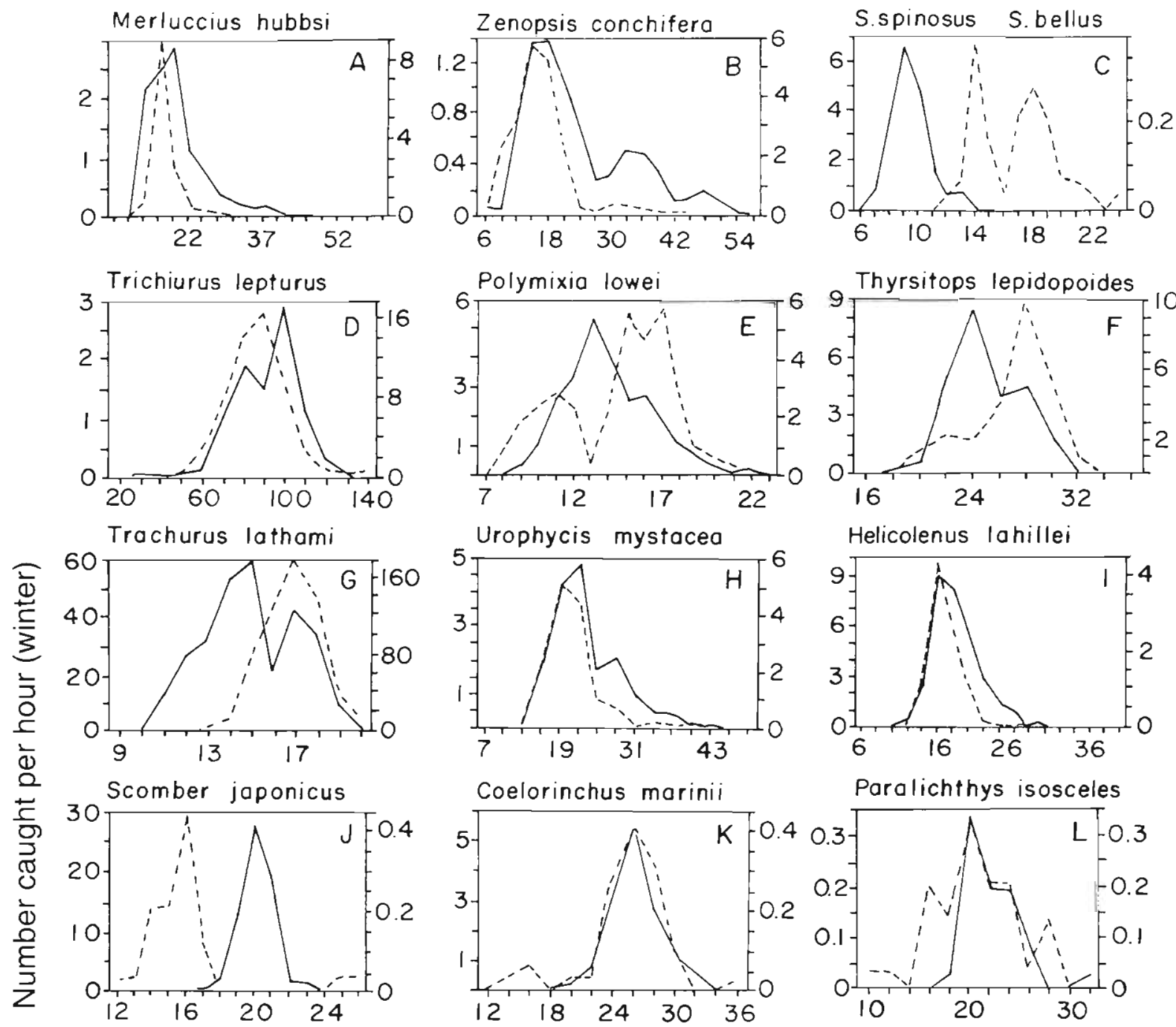

Helicolenus Iahillei

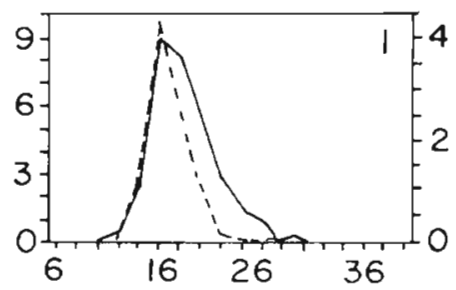

Coelorinchus marinii
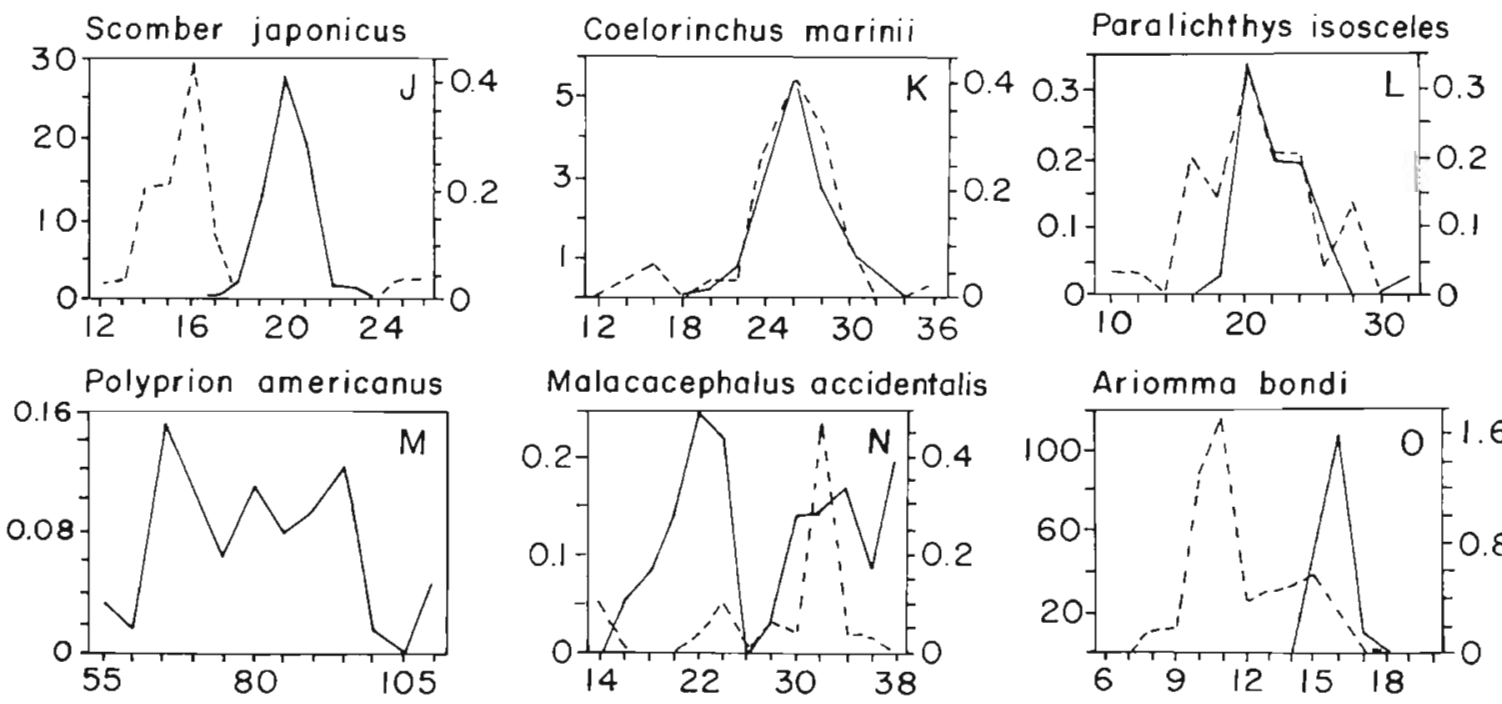

Malacacephalus accidentalis

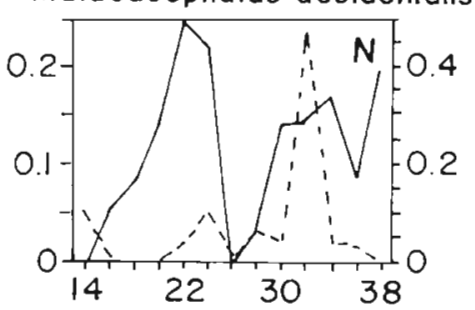

Ariomma bondi
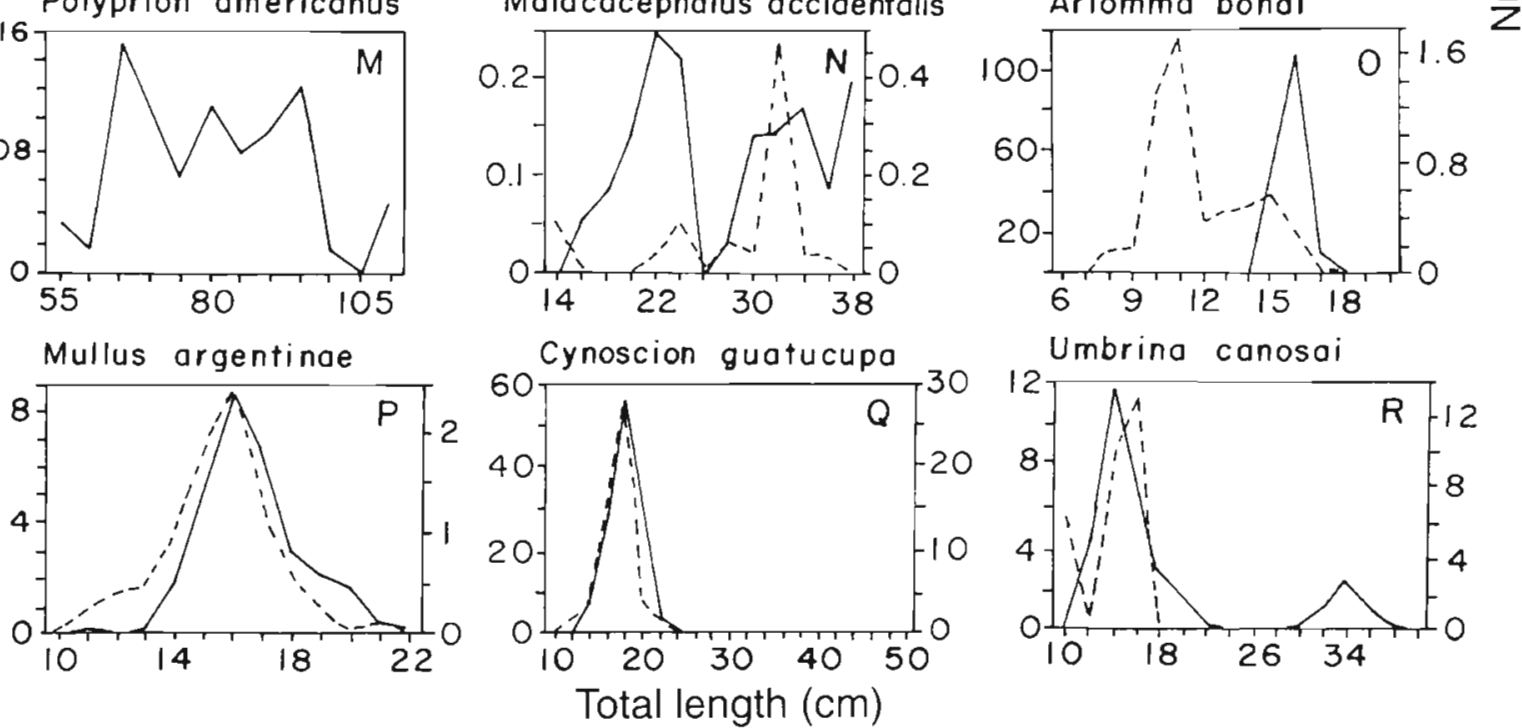

Fig. 3. Total length distributions of selected teleost species caught along the survey for the winter (solid lines) and summerautumn cruises (dashed lines) 
at 50 to $120 \mathrm{~m}$ depth (Capitoli \& Haimovici 1993). The congeneric species Synagrops bellus occurred 16 times, in the same depth and temperature ranges as $S$. spinosus, but was more abundant in deeper waters. Their size distributions did not overlap in the samples (Fig. 3C).

Trichiurus lepturus. Distributed worldwide in tropical and warm-temperate waters, the cutlassfish was found mainly on the outer shelf. Mean weight was $375 \mathrm{~g}$ and total length varied between 27 and $143 \mathrm{~cm}$ but most fishes were longer than $70 \mathrm{~cm}$ (Fig. 3D). Caught in all cruises, the cutlassfish was more abundant in the south, and during the summer. Large adults caught on the outer shelf fed mostly on Maurolicus muelleri and euphausiids. Spawning specimens were found during May and September cruises, when specimens from the shelf were still maturing (Martins 1992).

Polymixia lowei. The beardfish is distributed in the western Atlantic from Uruguay to New Jersey, USA. It occurred throughout the surveyed area, but was more common in the northern region. In the warm season cruises 2 modal groups, $11 \mathrm{~cm}$ and $17 \mathrm{~cm}$ long, were observed (Fig. 3E). No ripe or maturing specimens were found. P. lowei feeds mainly on small demersal fishes such as Bregmaceros atlanticus and benthic decapod crustaceans.

Thyrsitops lepidopoides. This gempylid fish is limited to the Atlantic and Pacific coasts of southern South America. More frequent in the north, it presented 2 modal groups of 23 and $28 \mathrm{~cm}$ long in winter and summer, respectively (Fig. 3F). In winter and spring it was found to feed on young Engraulis anchoita and euphausids on the shelf (Schwingel 1991, based on 11 examples 72 to $248 \mathrm{~mm}$ long). Ripe females over $21 \mathrm{~cm}$ were observed in November and March.

Trachurus lathami. This jack mackerel ranges from the Gulf of Maine to Argentina. Rather abundant and occasionally landed by sardine or mackerel purseseiners along the coast of southern and southeastern Brazil, it was caught at 19 stations up to $180 \mathrm{~m}$ deep, representing $21.03 \%$ of the catch and being more common towards the north. Length ranged from 9 to $20 \mathrm{~cm}$ (Fig. 3G). In winter and spring it preys mainly upon euphausiids and copepods (Schwingel 1991).

Urophycis mystacea. This is a type of hake confined to the waters from Argentina to Rio de Janeiro. It was more frequent in the south in both winter and summerautumn cruises. Most of the fish caught were immature specimens, a few maturing females over $30 \mathrm{~cm}$ long being observed in May and July. Its food consists of benthic crabs and shrimps but also small demersalpelagic fishes and cephalopods. The congeneric species Urophycis brasiliensis has the same geographical distribution, being more abundant in shallower waters, where it is fished by trawlers. It occurred in 8 hauls below $214 \mathrm{~m}$ depth. Total length ranged from 20 to $37 \mathrm{~cm}$ (Fig. 3H). On the shelf coastal waters it feeds on shrimps, crabs and to a lesser degree on fish.

Helicolenus lahillei. This species is known to occur from the coast of Santa Catarina State to northeastern Argentina. Most of the specimens were juveniles, those over $23 \mathrm{~cm}$ long were caught mainly in winter and some of the females were ripe (Fig. 3I). Seldom caught on the shelf, this is one of the most abundant demersal species on the break and upper slope. It is rather abundant in the Rio de la Plata Front over $100 \mathrm{~m}$ deep (Otero et al. 1982) where the larger specimens prey upon small benthic invertebrates and fishes (Migliore 1988). In the study area it feeds mostly on myctophid fishes, squids and anomuran crustaceans (Munida spp.).

Scomber japonicus. Chub mackerel is a cosmopolitan species, inhabiting warm and temperate waters. It was mainly caught in the south in winter below $180 \mathrm{~m}$ depth. The total length ranged from 17 to $23 \mathrm{~cm}$ in winter, with a mode of $20 \mathrm{~cm}$. In summer, its size ranged from 12 to $26 \mathrm{~cm}$, the mode being $16 \mathrm{~cm}$ (Fig. 3J). This mackerel feeds on euphausiids and copepods (Schwingel 1991). A single migratory stock living between Rio de Janeiro and Argentina was proposed by Seckendorff \& Zavala-Camin (1985) but morphometric differences were found by Perrota et al. (1990) when comparing fishes from southern Brazil and the Mar del Plata region.

Sciaenoides bergi. This species is known to occur from Rio de Janeiro to Argentina, being more frequent in the south. This is a temperate-water benthic invertebrate feeding species common on the Argentinean and Uruguayan shelf (Fernandez \& Norbis 1986).

Coelorinchus marinii. This macrourid occurs in the southwestern Atlantic from southern Brazil to Antarctica (Cohen et al. 1990). It was frequent below $350 \mathrm{~m}$ depth in winter in the entire area studied. Mean weight was $58 \mathrm{~g}$ and total length ranged from 12 to $34 \mathrm{~cm}$ (Fig. 3K). Some mature females over $250 \mathrm{~mm}$ were taken in all cruises. Its diet includes benthic crustaceans and polychaetes.

Paralichthys isosceles. This flatfish occurs from Rio de Janeiro to northern Patagonia. This species is typical of the outer shelf in the region throughout the year. Specimens smaller than $18 \mathrm{~cm}$ were found only in autumn (Fig. 3L). It preys upon small fishes, benthic crustaceans and cephalopods. Spawning seems to occur on the outer shelf in summer.

Polyprion americanus. The wreckfish is found in the Atlantic, Mediterranean and Indian Oceans, and waters around New Zealand. This is the only commercially fished teleost on the upper slope in the study area, where it is fished with a hand line on rocky bottoms (Wahlrich \& Peres 1990). This large fish had a mean weight of $9.4 \mathrm{~kg}$, and its total length ranged from 
56 to $113 \mathrm{~cm}$ (Fig. 3M). It occurred at all fished depths in temperatures varying from 6 to $16.2^{\circ} \mathrm{C}$. Reproduction seems to occur in the cold season. P. americanus feeds on fishes such as Merluccius hubbsi, Helicolenus lahillei and Urophycis mystacea, the crab Cheaceon notialis and the squid Illex argentinus.

Genypterus brasiliensis. Known to occur from Rio de Janeiro to Argentina, this fish was confused with G. blacodes, found from Uruguay to the southern tip of South America. This highly appreciated gadiform was caught in small numbers between 128 and $334 \mathrm{~m}$ deep, presenting a mean weight of $1.402 \mathrm{~kg}$ and a total length from 37 to $80 \mathrm{~cm}$. Specimens smaller than $60 \mathrm{~cm}$ were found only in summer. It was more abundant in winter and in the south. Only immature specimens were caught. The few stomachs observed contained benthic macrocrustaceans and unidentified fishes.

Lophius gastrophysus. The blackfin goosefish lives in waters between Rio de Janeiro and Argentina. A few specimens measuring 23 to $64 \mathrm{~cm}$ and with a mean weight of $1.183 \mathrm{~kg}$ were caught in 13 tows, from 180 to $300 \mathrm{~m}$ deep and from 11.5 to $17.0^{\circ} \mathrm{C}$.

Malacocephalus occidentalis. This is a benthic macrourid species found along the slope of both margins of the South Atlantic (Cohen et al. 1990). It was caught mostly at depths $>350 \mathrm{~m}$. Total length ranged from 15 to $39 \mathrm{~cm}$ (Fig. 3N). M. occidentalis was more abundant in the north. Ripe females over $35 \mathrm{~cm}$ long were found in July. It feeds on benthic macrocrustaceans, myctophid fishes and cephalopods.

Ariomma bondi. The silver-rag lives in the Atlantic Ocean, ranging from Maine to Uruguay in the western Atlantic. It occurs in large schools on mud or sand bottoms of the outer shelf, and feeds on small benthicdwelling animals, mainly crustaceans (Fischer 1978). It was present in 24 hauls, from 129 to $380 \mathrm{~m}$, but abundant only in 1 at $250 \mathrm{~m}$ depth near the Cape of Santa Marta Grande. Its mean weight was $49 \mathrm{~g}$ and total length ranged from 6 to $19 \mathrm{~cm}$ (Fig. 3O). Larger specimens were taken in spring and maturing females over $15 \mathrm{~cm}$ in winter.

Mullus argentinae. The goatfish is known to occur from Rio de Janeiro to Mar del Plata. It was caught on the outer shelf and was more common in the northern winter cruise. The mean weight was $65 \mathrm{~g}$ and total length varied from 11 to $22 \mathrm{~cm}$ (Fig. 3P). It feeds on benthic invertebrates.

Cynoscion guatucupa syn. Cynoscion striatus. This weakfish (for taxonomic status see Figueiredo 1992) occurs from Rio de Janeiro to Argentina, and is an important commercial species in the coastal trawl fishery of southern Brazil, Uruguay and Argentina (Haimovici et al. 1989b, Vieira 1990). It is a shelf species which was relatively abundant in many of the hauls $<165 \mathrm{~m}$ depth, and occurs mainly in winter in the south and at bottom temperatures over $15.8^{\circ} \mathrm{C}$. Sizes ranged from 11 to $50 \mathrm{~cm}$ (Fig. 3Q). Most specimens taken were juveniles but some adults were caught in the winter.

Umbrina canosai. A migratory species between Argentina and southern Brazil, where it is intensively fished by trawlers, this sciaenid is found in small quantities up to Rio de Janeiro. In the survey it was caught below $165 \mathrm{~m}$ depth and at temperatures over $15.2^{\circ} \mathrm{C}$. Sizes ranged between 10 and $40 \mathrm{~cm}$ (Fig. 3R). It was more frequent in both northern-area cruises in May and September. Adult spawners were observed in the winter cruise at $130 \mathrm{~m}$ depth at $31^{\circ} \mathrm{S}$. Specimens over $25 \mathrm{~cm}$ were not common at depths over $75 \mathrm{~m}$ but some commercial catches of larger specimens have been reported (Haimovici 1982). U. canosai is a long-living and slow-growing species that spawns in spring and feeds on benthic invertebrates (Haimovici \& Reis 1984, Haimovici \& Cousin 1989, Haimovici et al. 1989a).

Pagrus pagrus. The red porgy is an Atlantic and Mediterranean species (Manooch \& Hassler 1978). A few specimens measuring from 11 to $50 \mathrm{~cm}$ total length and $705 \mathrm{~g}$ mean weight occurred in 6 hauls at depths $<185 \mathrm{~m}$ and bottom temperatures from 15 to $17^{\circ} \mathrm{C}$. It migrates to southern Brazil in winter together with cold waters on the mid-shelf (Yesaki \& Barcellos 1974 Haimovici 1991). P. pagrus feeds on a wide variety of benthic and demersal fish and invertebrates (Capitoli \& Haimovici 1993).

Porichthys porossissimus. Known to occur from Argentina to Rio de Janeiro, the midshipman was taken between 130 and $212 \mathrm{~m}$ deep. It was relatively abundant in only 2 hauls, one in winter at $178 \mathrm{~m}$ and the other in summer at $134 \mathrm{~m}$

Diaphus dumerilii. A common and abundant mesopelagic tropical species widely distributed in the Atlantic Ocean, it probably consists of a number of populations. In the southwestern Atlantic adults not yet sexually mature occurred near the continent in relatively cold waters under steep thermoclines and were considered an 'expatriate population' (Hulley 1981). It measured 4 to $13 \mathrm{~cm}$ long with a mean weight of $3 \mathrm{~g}$. It was the most frequent myctophid in the survey, occurring in 15 hauls from 197 to $587 \mathrm{~m}$ deep and from 4 to $15.7^{\circ} \mathrm{C}$. Undersampled by our gear, it was found in the stomach contents of several fishes and seems to be very abundant and important in the trophic relations on the slope. Catches up to $15 \mathrm{t}^{\text {haul }}{ }^{-1}$ were recorded off Uruguay and northern Argentina (Hulley 1981). The congeneric species $D$. effulgens was caught in only 2 hauls below $458 \mathrm{~m}$ depth.

Argentina striata. Found along the western Atlantic from Nova Scotia to Uruguay, this studied argentine was taken in small numbers between 150 and $450 \mathrm{~m}$ depth, but more frequently up to $250 \mathrm{~m}$ deep in the northern region. 
Antigonia capros. The boarfish is a cosmopolitan species in temperate and tropical waters, except in the eastern Pacific. In winter only juveniles were taken, ripe females over $15 \mathrm{~cm}$ having been caught in March. Boarfish occurred more frequently at temperatures over $12.5^{\circ} \mathrm{C}$ and depths up to $250 \mathrm{~m}$. It feeds mostly on hyperiid amphipods, euphausiids and small squid. Most catches occurred in the northern spring and southern summer cruises.

Benthodesmus elongatus. The frostfish is found in subtropical and temperate waters of the southern hemisphere. Frostfish were more abundant in July in the north and in summer in the south, where larger specimens were more frequent. A few examined stomach contents contained euphausiids and myctophids.

Priacanthus arenatus. The bigeye is known to occur from Canada to northern Argentina. It was caught in 4 hauls from 176 to $587 \mathrm{~m}$ deep, and from 4 to $16.3^{\circ} \mathrm{C}$. Its mean weight was $1.586 \mathrm{~kg}$ and total length ranged from 21 to $53 \mathrm{~cm}$. Most were caught in a summer haul at $188 \mathrm{~m}$ depth and $16.3^{\circ} \mathrm{C}$ at $31^{\circ} 09^{\prime} \mathrm{S}$.

Maurolicus muelleri. This small mesopelagic fish is common along the continental slope of all oceans up to the $400 \mathrm{~m}$ isobath (Weitzman 1986). It was found at only 8 stations and measured from 4 to $5 \mathrm{~cm}$, but was frequent in the stomach contents of several demersalpelagic fish caught and appears an important species in the food chains in the study area. The species spawns in midwater on the shelf break, mainly from autumn to spring, eggs and larvae being retained in the front between tropical waters of the Brazil Current and colder and less saline coastal waters, and carried over the shelf by the partial upwelling of subtropical waters (Weiss et al. 1988). Frequent and abundant in plankton samples, its stock size was estimated from egg counts as being over $1600 \mathrm{t}$ (Weiss et al. 1988). It feeds on planktonic crustaceans such as copepods and hyperiid amphipods.

\section{Distribution pattern, relative abundance and number of species}

Eigenvalues of Axes 1 to 4 in seasonal DECORANA runs and correlation coefficients between depth, bot- tom temperature and latitude with the scores of the hauls along the 4 axes are shown in Table 3. Depth and temperature were strongly correlated with Axis 1 in both seasons and to a lesser degree with Axis 2 in summer-autumn. Latitude only correlated with Axis 4 in winter-spring. Species and stations simultaneously ordered following DCA Axis 1 in both seasons are shown in Table 4. A more-or-less continuous substitution of species was observed both in winter and summer-autumn with increasing depth and decreasing bottom temperature, probably due to the lack of discontinuities in the bottom topography and morphology in the trawling areas.

Depth ranges. Total teleost mean catch decreased 6-fold along the depth gradient, from 170.9 (120 to $179 \mathrm{~m}$ ) to $26.3 \mathrm{~kg} \mathrm{~h}^{-1}$ (450 to $587 \mathrm{~m}$ ). The number of species decreased from 61 to 27 in the same depth range. Demersal-pelagic catches decreased sharply below $180 \mathrm{~m}$ depth with a partial recovery due to a large single catch of Ariomma bondi between 250 and $349 \mathrm{~m}$. The demersal-benthonic catches decreased little with depth, ranging between 29.4 and $21.4 \mathrm{~kg} \mathrm{~h}^{-1}$. The total number of species decreased slowly from 61 to 45 down to $350 \mathrm{~m}$ depth and to 26 and 27 in the last 2 depth ranges, showing a similar pattern for demersal-pelagic and demersal-benthic species. The mean number of species per haul decreased more gently, from over 14 (to $250 \mathrm{~m}$ deep) to 8.1 (below $350 \mathrm{~m}$ ) (Table 5).

Latitudes and seasons. Mean total catches ranged from 74.4 to $97.5 \mathrm{~kg} \mathrm{~h}^{-1}$, and total number of species varied from 53 to 67 per cruise, both values being higher in winter cruises (Table 5). Mean number of species ranged from 10.8 to 14.2 . The catches of demersal-pelagic bony fishes differed little between seasons, ranging from 54.4 to $66.8 \mathrm{~kg} \mathrm{~h}^{-1}$, being slightly higher in both northern cruises; the number of species was lower, 19 compared to 23 and 24 , in the southern cruises. Demersal benthic fish catches in winter and spring ( 38.5 to $36.9 \mathrm{~kg} \mathrm{~h}^{-1}$ ) were more than 2 -fold the catch in summer and early autumn (11.8 to $16.0 \mathrm{~kg} \mathrm{~h}^{-1}$ ) but the number of species was similar, ranging from 28 to 32 . The difference was due mostly to some deep-water species such as Polyprion ameri-

Table 3. Eigenvalues of Axes 1 to 4 in a detrended correspondence analysis (DCA) and correlation coefficients between depth, bottom temperature and latitude with the scores of fishery hauls on Axes 1 to 4 ('significant at $5 \%$ probability level)

\begin{tabular}{|c|c|c|c|c|c|c|c|c|}
\hline & \multicolumn{4}{|c|}{ Winter and spring cruises } & \multicolumn{4}{|c|}{ Summer and autumn cruises } \\
\hline & Axis 1 & Axis 2 & Axis 3 & Axis 4 & Axis 1 & Axis 2 & Axis 3 & Axis 4 \\
\hline Eigenvalues & 0.66 & 0.35 & 0.19 & 0.13 & 0.64 & 0.42 & 0.31 & 0.19 \\
\hline Depth & $0.89^{\circ}$ & 0.02 & 0.09 & 0.07 & $0.81^{\circ}$ & $0.17^{\circ}$ & 0.04 & $<0.01$ \\
\hline Bottom temperature & $0.84^{\circ}$ & 0.01 & $<0.01$ & 0.08 & $0.78^{\circ}$ & $0.18^{\circ}$ & 0.06 & 0.03 \\
\hline Latitude & 0.09 & $<0.01$ & $<0.01$ & $0.49^{\circ}$ & 0.02 & $<0.01$ & $<0.01$ & 0.05 \\
\hline
\end{tabular}


Table 4. Species and hauls ordained by Axis 1 on a detrended correspondence analysis (DECORANA), during 2 seasons on the outer shelf and upper slope of southern Brazil between 1986 and 1987. Abundance scale in no. of specimens per hour: $<10$ (1), 10-99 (2), 100-999 (3), 1000-9999 (4), >10000 (5)

\begin{tabular}{|c|c|c|c|c|c|c|c|c|c|c|c|c|c|c|c|c|c|c|c|c|c|c|c|c|c|c|c|c|c|}
\hline $\begin{array}{l}\text { Temperature and depth } \\
\text { in each haul: }\end{array}$ & $\begin{array}{l}U \\
0 \\
0 \\
\infty \\
v \\
E \\
E \\
\sigma \\
\sigma \\
\forall\end{array}$ & 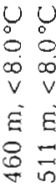 & 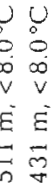 & 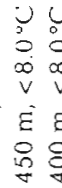 & & & $\begin{array}{l}U \\
0 \\
n \\
= \\
E \\
8 \\
8 \\
\bar{c}\end{array}$ & & & & 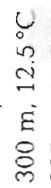 & & 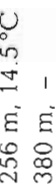 & & 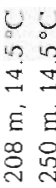 & & & & & & & & 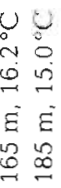 & & & & 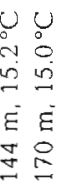 & & 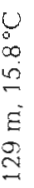 \\
\hline \multicolumn{30}{|l|}{ Winter and spring cruises } \\
\hline Setarches guentheri & & & 1 & & & & & & & & & & & & & & & & & & & & & & & & & & \\
\hline Stomias affinis & & & 1 & 1 & & & & & & & & & & & & & & & & & & & & & & & & & \\
\hline Diaphus dumerilii & 3 & 12 & 22 & 2 & 1 & l & & 1 & 1 & 2 & & & & & & & & & & & & & & & & & & & \\
\hline Xenolepidichthys dalgleishi & & & 12 & 2 & 1 & 1 & 2 & & & 1 & & & & & & & & & & & & & & & & & & & \\
\hline Polymetme corythaeola & & & 2 & 1 & & & & 1 & & 1 & & & & & & & & & & & & & & & & & & & \\
\hline Chlorophthalmus agassizi & & & 1 & & & & 1 & & & & & & & & & & & & & & & & & & & & & & \\
\hline Coelorinchus marinui & 1 & 12 & 23 & 31 & 1 & 1 & 2 & & & 21 & & & & & & & & & & & & & & & & & & & \\
\hline Malacocephalus occidentalis & & 11 & 11 & 11 & 1 & & 2 & & 11 & 1 & & & & 1 & & & & 1 & & & & & & & & & & & \\
\hline Helicolenus lahillei & & 22 & 22 & 2 & 1 & 3 & 1 & & 12 & 21 & 1 & & & & & & & & & & & & & & & & & & \\
\hline Lepidopus sp. & & & 1 & 1 & & & & & & 1 & & & & 1 & & 1 & & & & 1 & & & & & & & & & \\
\hline Hoplostethus occidentalis & & 1 & 11 & & & & 2 & & & & & & 1 & & & & & & & & & & & & & & & & \\
\hline Bregmaceros atlanticus & & & 1 & & & & & & & & & 1 & & & & & & & & & & & & & & & & & \\
\hline Polyprion americanus & & & 2 & 1 & & 2 & 1 & & & 12 & & & & & & & & & & & & & & & & & & & \\
\hline Benthodesmus elongatus & & 11 & 11 & 2 & 1 & L & 1 & 1 & & 11 & & & 3 & 1 & & & & & & & & & 1 & 1 & & & & & \\
\hline Synagrops bella & 1 & & 1 & 11 & 11 & l. & 2 & & 11 & 11 & & 1 & & 1 & & & & 1 & & & & & & & & & & & \\
\hline Parasudis truculenta & & & 1 & & & & & & & 1 & & & 2 & 1 & & 1 & & & & & & & & & & & 1 & & \\
\hline Polymixia lowei & 1 & & 1 & 2 & & 2 & 2 & & 21 & 13 & 1 & 2 & 21 & 1 & 2 & & & & & & & & & & & & & & \\
\hline Merluccius hubbsi & 1 & & 2 & 11 & 11 & 1 & 2 & 1 & 12 & 22 & 1 & & 2 & 2 & 1 & & 2 & & 3 & & & 1 & & & & & & & \\
\hline Evoxymetopon taeniatus & & & & & & & 1 & & 21 & 1 & & & & & 1 & 1 & 1 & 3 & & & 1 & 1 & 2 & 2 & 1 & 1 & & & \\
\hline Notopogon fernandezianus & & & & & & & 1 & & & 1 & & & & & 1 & & & & & 1 & & & & & & & 1 & & 1 \\
\hline Urophycis mystacea & & 12 & 21 & & 11 & 1 & 2 & & & 21 & & & 1 & 3 & & & & & 1 & & & & & & & & & & \\
\hline Symbolophorus barnardi & & & & & & & & & & & & & & 1 & & & & 3 & & & 1 & & 1 & 1 & & 2 & & & \\
\hline Decapterus tabl & & & & & & & & & & & & & & 1 & & & & & & & & & & & & & & & \\
\hline Bembrops heterurus & & 1 & 1 & & & & 1 & & & 1 & & & 1 & 1 & 1 & & & & & & & & & & & & & & \\
\hline Lopholatilus villarii & & & & & & & 1 & & & & & & & 1 & & 1 & 1 & 1 & 1 & & 1 & & & & & & & & \\
\hline Lophius gastrophysus & & & & & & & 1 & & & 1 & & 1 & & & & & & & & & & & & & & 1 & 1 & & \\
\hline Peristedion sp. & & & & & & & & & & 2 & & & 1 & 1 & 3 & 1 & & & & 1 & & & & & & & 1 & 1 & \\
\hline Maurolicus muelleri & & & & & & 1 & & & & & 3 & & 3 & & & & 2 & & & & & & & & & & & & \\
\hline Synagrops spinosus & & & & & 1 & 1 & & & & 12 & 1 & 1 & 1 & 2 & & & & & & & & & & 3 & & & & & \\
\hline Zenopsis conchifera & & & & & & 1 & & & & 13 & 1 & & 2 & 1 & 1 & 1 & 1 & 2 & 1 & 1 & 1 & 1 & 1 & & & & & & 1 \\
\hline Argentina striata & & & & 1 & & & & & & 1 & & 1 & 1 & 1 & & 2 & & 1 & & 1 & 1 & & 1 & 1 & 1 & 2 & 1 & & 1 \\
\hline Citharichthys cornutus & & & & & & & & & & & & & & 1 & & 21 & 2 & & 1 & & 1 & 1 & & & & & & & \\
\hline Genypterus brasiliensis & & & & & & & 1 & & & 1 & & & & 1 & & 1 & & & & & & & & & & & & & \\
\hline Ariomma bondi & & & & & & & 1 & & & & & 12 & 24 & 1 & & 1 & & 1 & & 1 & 1 & & 1 & & 1 & 1 & & & \\
\hline Saurida caribbaea & & & & & & & & & & 1 & & & 1 & & 14 & 41 & 1 & 1 & & 1 & 1 & 1 & 1 & & 3 & & & & \\
\hline Scomber japonicus & & & & & & & & & & 2 & & & & 2 & & & 1 & 1 & 1 & & & 1 & & & & & 1 & & \\
\hline Macrorhamphosus scolopax & & & & & & & & & & & & 1 & & & 1 & 3 & & 3 & & 4 & & & 1 & & 1 & & & & \\
\hline Sciaenoides bergi & & & & & & & & & & & & & & 1 & 1 & & & 1 & 2 & & & & & & & & & 1 & \\
\hline Pontinus rathbuni & & & & & & & & & & & & & & & & & & & & 1 & & & & 1 & & & 1 & & \\
\hline Porichthys porosissimus & & & & & & & & & & & & & & 1 & & 1 & & 1 & & 1 & & & & & & & & & \\
\hline Serranus atrobranchus & & & & & & & & & & & & & & 1 & & & & 3 & 1 & & & & & & & 2 & & & \\
\hline Pristipomoides freemani & & & & & & & & & & & & & & & & 1 & & & & 1 & & & 1 & & 1 & & & & \\
\hline Pikea rosea & & & & & & & & & & & & & & & & 2 & & & & 1 & & & & & & & & & \\
\hline Gymnothorax ocellatus & & & & & & & & & & & & & & & & & & 1 & & & 1 & & & & & & & & \\
\hline Thyrsitops lepidopoides & & & & & & & & 1 & & 1 & & & & 1 & 1 & & & & 1 & & 1 & & & & & & & & \\
\hline Prionotus nudigula & & & & & & & & & 1 & & & & & & 1 & 1 & 1 & 2 & 1 & & 1 & 3 & & 3 & 2 & & 2 & 1 & 1 \\
\hline Priacanthus arenatus & & & & & & & & & & & & & & & & 1 & & & 2 & 1 & 1 & & 1 & & 1 & & 1 & 2 & \\
\hline Pagrus pagrus & & & & & & & & & & & & & & & & & & & & 1 & 1 & & & & & & & & \\
\hline Paralichthys isosceles & & & & & & & & & & & & & & & 1 & 2 & & & & 2 & & & 1 & & & & 1 & & \\
\hline Synchiropus agassizii & & & & & & & & & & & & & & & & & 1 & 1 & 1 & & 1 & & 1 & 1 & 1 & 1 & & 1 & 1 \\
\hline Trichiurus lepturus & & & & & & & & & & 1 & & & & 1 & 1 & 1 & & & 1 & & & & & & & 1 & & & \\
\hline Mullus argentinae & & & & & & & & & & & & & & & 2 & 1 & & 2 & 3 & 1 & 2 & & & 1 & & 3 & 2 & 2 & 2 \\
\hline Urophycis brasiliensis & & & & & & & & & & & & & & & & 2 & 2 & 2 & 2 & 2 & 1 & 2 & 2 & 2 & 3 & 2 & 3 & 2 & 2 \\
\hline Antigonia capros & & & & & & & & & & & & & & 1 & & & 1 & & 1 & & & & & & & & & 1 & 1 \\
\hline Cynoscion guatucupa & & & & & & & & & & & & & & & & 1 & 2 & 2 & & 1 & & 1 & 3 & & 1 & & 23 & 1 & \\
\hline Cookeolus japonicus & & & & & & & & & & & & & & & & & & & & & & & 3 & 4 & & 4 & & & 2 \\
\hline Prionotus punctatus & & & & & & & & & & & & & & & & & & 1 & & & & & & & & & & & 1. \\
\hline Trachurus lathami & & & & & & & & & & & & & & & & & & & & & & & & 1 & & 2 & & & \\
\hline Pseudopercis spp. & & & & & & & & & & & & & & & & & 2 & 3 & & & 2 & & 2 & 4 & 4 & 3 & 3 & 3 & 4 \\
\hline Umbrina canosai & & & & & & & & & & & & & & & & & & & & & & & & 1 & & & 1 & & \\
\hline Engraulis anchoita & & & & & & & & & & & & & & & & & & & & & & & 1 & 3 & & 2 & & 3 & 3 \\
\hline Caulolatilus chrysops & & & & & & & & & & & & & & & & & & & & & & 1 & & & 1 & & 3 & 2 & 1 \\
\hline
\end{tabular}

(Table continued on next page) 
Temperature and depth in each haul:

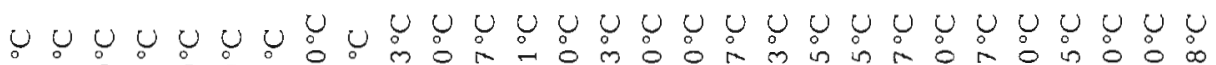

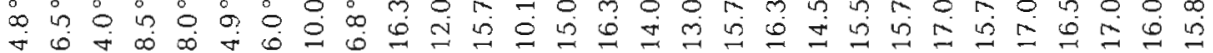

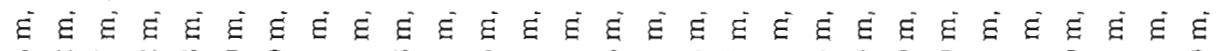
冓 N
Summer and autumn cruises

Symbolophorus barnardi

Polymetme corythaeola

Diaphus dumerilii

Benthodesmus elongatus

Diaphus effulgens

Helicolenus lahillei

Coelorinchus marinii

Synagrops bellus

Xenolepidichthys dalgleishi

Malacocephalus occidentalis

Parasudis truculenta

Polyprion americanus

Priacanthus arenatus

Notopogon fernandezianus

Lepidopus sp.

Pontinus rathbuni

Antigonia capros

Maurolicus muelleri

Pikea rosea

Sciaenoides bergi

Polymixia lowei

Pristipomoides freemani

Serranus atrobranchus

Synagrops spinosus

Argentina striata

Urophycis mystacea

Merluccius hubbsi

Caulolatilus chrysops

Setarches guentheri

Macrorhamphosus scolopax

Zenopsis conchifera

Lophius gastrophysus

Genypterus brasiliensis

Peristedion gracile

Ariomma bondi

Saurida caribbaea

Evoxymetopon taeniatus

Paralichthys isosceles

Bembrops heterurus

Citharichthys cornutus

Urophycis brasiliensis

Trichiurus lepturus

Gymnothorax ocellatus

Decapterus tabl

Thyrsitops lepidopoides

Synchiropus agassizii

Prionotus nudigula

Porichthys porosissimus

Trachurus lathami

Scomber japonicus

Cynoscion guatucupa

Mullus argentinae

Pagrus pagrus

Umbrina canosai

Prionotus punctatus
2

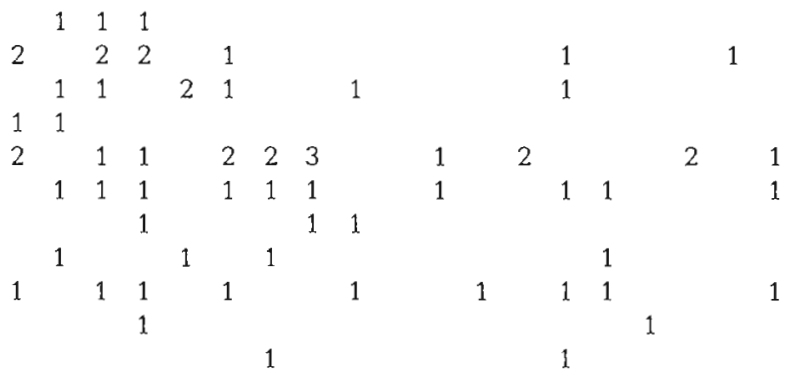

1

2

$\begin{array}{lll}1 & 1 \\ 1 & 1\end{array}$

2

$\begin{array}{llllllll}1 & & 1 & 2 & 1 & 1 & & 1 \\ 3 & 1 & & & 3 & & 1 & 2 \\ & & & 2 & & 3 & & 2\end{array}$

1

$\begin{array}{lllllllllllll}2 & 1 & 2 & 1 & 1 & 2 & 2 & 1 & 2 & 3 & 1 & 3\end{array}$

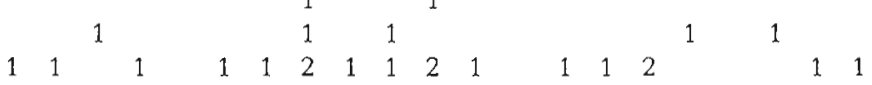

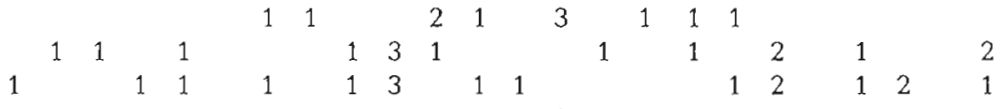

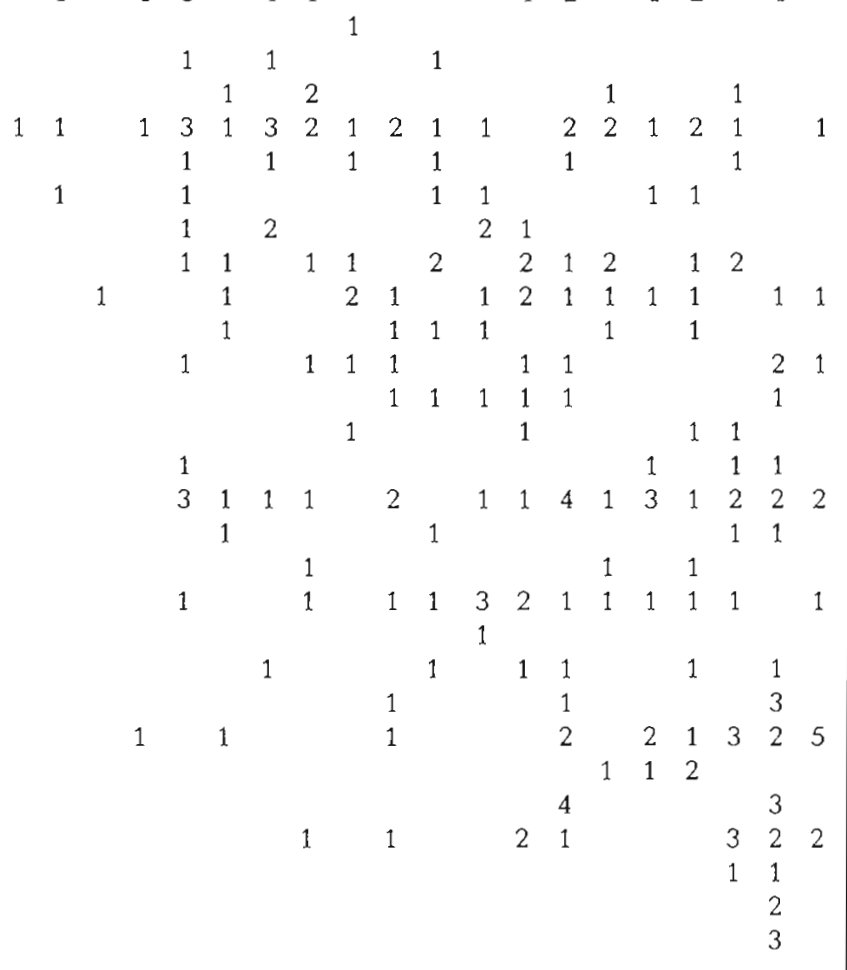


Táble 5. Catch $\left(\mathrm{kg} \mathrm{h}^{-1}\right)$ and number of teleost species per cruise and depth range in a bottom trawl survey off southern Brazil during 1986 and 1987

\begin{tabular}{|c|c|c|c|c|c|c|c|c|c|}
\hline & \multicolumn{4}{|c|}{ Cruise } & \multicolumn{5}{|c|}{ Depth range (m) } \\
\hline & $\begin{array}{c}\text { Jul } 1986 \\
\text { Winter } \\
\text { South }\end{array}$ & $\begin{array}{l}\text { Sep } 1986 \\
\text { Spring } \\
\text { North }\end{array}$ & $\begin{array}{c}\text { Mar } 1987 \\
\text { Summer } \\
\text { South }\end{array}$ & $\begin{array}{c}\text { May } 1987 \\
\text { Autumn } \\
\text { North }\end{array}$ & $120-179$ & $180-249$ & $250-349$ & $350-449$ & $450-587$ \\
\hline No. of hauls & 17 & 19 & 17 & 12 & 20 & 14 & 14 & 8 & 9 \\
\hline Total bony fish catches & 95.9 & 97.5 & 74.4 & 82.9 & 170.9 & 48.4 & 79.1 & 37.9 & 26.3 \\
\hline Mesopelagic species & 3.0 & 0.0 & 2.9 & 0.0 & 2.6 & 0.1 & 2.9 & 0.0 & 0.8 \\
\hline Demersal-pelagic species & 54.4 & 60.6 & 59.7 & 66.8 & 138.9 & 26.9 & 43.1 & 15.6 & 1.0 \\
\hline Demersal-benthonic species & 38.5 & 36.9 & 11.8 & 16.0 & 29.4 & 21.4 & 33.1 & 22.2 & 24.4 \\
\hline Total no. of species & 67 & 62 & 56 & 53 & 61 & 54 & 45 & 26 & 27 \\
\hline Mesopelagic species & 8 & 4 & 8 & 2 & 5 & 3 & 5 & 3 & 6 \\
\hline Demersal-pelagic species & 23 & 24 & 19 & 18 & 24 & 19 & 17 & 11 & 9 \\
\hline Demersal-benthonic species & 35 & 33 & 28 & 32 & 32 & 31 & 22 & 11 & 11 \\
\hline Mean no. of species per haul & 14.2 & 11.4 & 11.5 & 10.8 & 14.4 & 14.5 & 11.0 & 8.1 & 8.0 \\
\hline
\end{tabular}
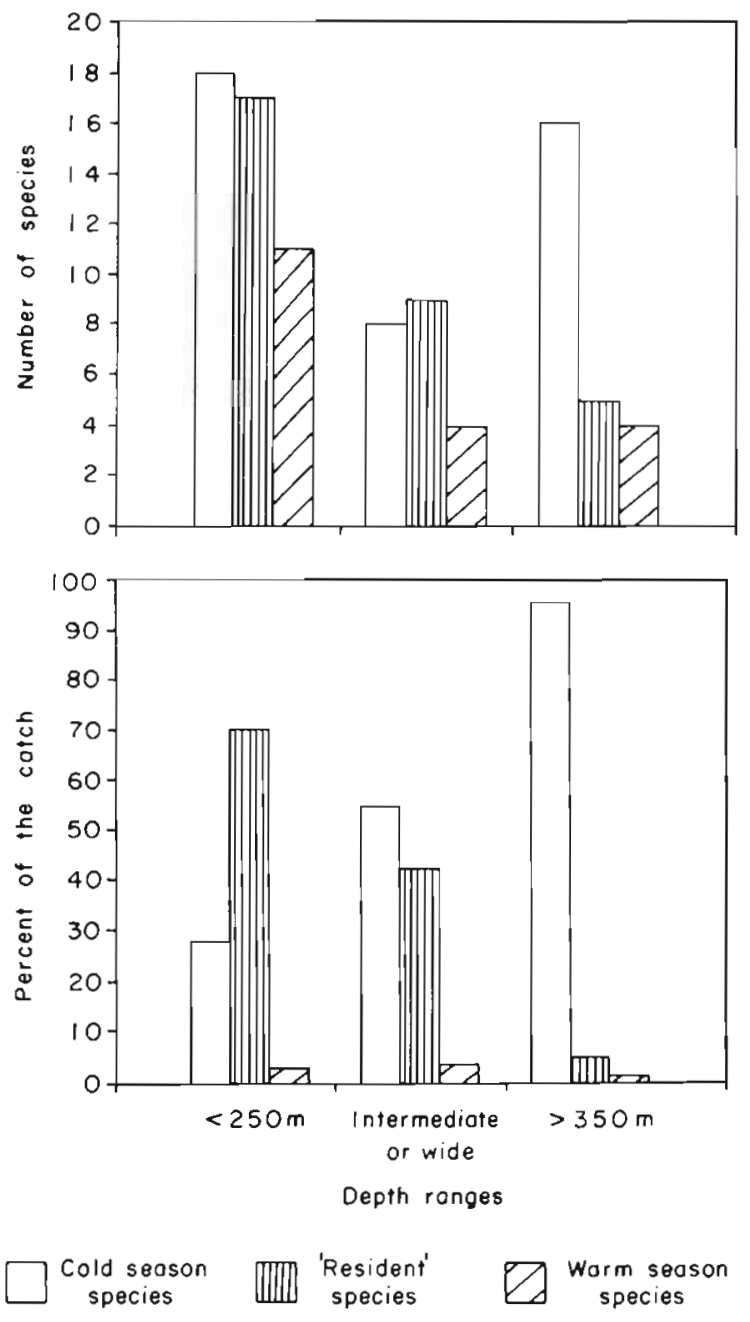

Fig. 4. Catches and number of teleost species per depth range classified according to their relative abundance in the winterspring (cold) and summer-autumn (warm) cruises (for further details on the classification see text) canus, Helicolenus lahillei and Coelorinchus marinii. Few mesopelagic species were caught, mainly myctophids, and were more abundant in both southern cruises.

Most species occurred in both winter and summerautumn cruises (Table 2) but, because the study area is in the western boundary of the Subtropical Convergence, some seasonal pattern in the bony fish fauna is expected to occur. To investigate this possibility, the species were classified according to their relative abundance in the winter and summer-autumn cruises (Fig. 4). Species were grouped into: 'cold season species', those in more than $75 \%$ of the catches in the winter-spring cruises; and 'warm season species', those in more than $75 \%$ of the catches in summer-autumn cruises; the rest were included in a 'resident species' group. Overall, $42.5 \%$ of the catches were composed of 42 cold season species, and 19 warm season species amounted to $1.8 \%$ of the catch. A total of 32 resident species represented $55.7 \%$. To account for bottom depth, species were arranged in 3 groups: (1) those found above $250 \mathrm{~m}$ depth, (2) those found below $350 \mathrm{~m}$ depth, and (3) those caught at intermediate depths or over a wider depth range. Warm season species were of little importance in all 3 ranges $(2.4,3.3$ and $3.3 \%$ of the catch) and were more numerous on the outer shelf. Resident species were more abundant and numerous at $<250 \mathrm{~m}(69.9 \%)$, second in intermediate depth $(42.1 \%)$ and scarce at $>350 \mathrm{~m}(4.2 \%)$. The opposite was observed for the cold season species $(27.7 \%$, $54.6 \%$ and $95.0 \%$ respectively in each depth range) which were almost as numerous on the outer shelf as at greater depth. With increasing depth, the relative abundance of species that occur year-round decreases, meanwhile it was higher for fishes that occur mostly in winter, the warm season species having little quantitative importance in the catches. 


\section{DISCUSSION}

The southern Brazilian coast is on the boundary between subtropical and warm temperate regions. Figueiredo (1981), studying the continental shelf fish fauna, set the limits of the transitional zoogeographic Argentinean Province at Cabo Frio $\left(21^{\circ} \mathrm{S}\right)$ and Valdés Peninsula $\left(42^{\circ} \mathrm{S}\right)$, between the Caribbean and Patagonian provinces (Palacio 1982). The Argentinean Province has a low proportion of endemic fish species, ca $10 \%$, characterized by high tolerance to temperature and salinity variations (Figueiredo 1981) as a consequence of the influence of the seasonal shift of the Subtropical Front and the (seasonal) upwelling of cold waters off southeastern Brazil (Matsuura 1986).

In this survey, species endemic to the Argentine Province, e.g. Umbrina canosai, Urophycis brasiliensis, Mullus argentinae, Paralichthys isosceles, and Cynoscion guatucupa, were found mostly on the outer shelf, and were more abundant in shallower waters. Many species with a wide Western Atlantic distribution, stretching from northern Argentina to the northern hemisphere, in some cases up to Canada, are found along the upper slope, e.g. Trachurus lathami, Scomber japonicus, Ariomma bondi, Polymixia lowei, and Polyprion americanus. In deeper waters species with a wider geographic distribution, even cosmopolitans, are found, e.g. the benthic and demersal macrourids, trichiurids, mesopelagic myctophids, Maurolicus muelleri and Zenopsis conchifera. Species from cold temperate waters abundant in southern Argentina were scarce in this survey; only Merluccius hubbsi was numerically abundant. Except for some demersal-benthonic species on the outer shelf, most abundant species were demersal-pelagic or hard bottom species.

Our results show a weak latitudinal gradient in the composition of fish fauna. This is expected as there are no geographic or hydrographic barriers and the amplitude in the bottom temperatures between north and south extremes of the study area in each season was small. Instead, the north-south shift of the western boundary of the Subtropical Convergence appears as the main factor responsible for seasonal changes in species abundance. Variation in demersal-pelagic species abundance was small, as at these latitudes the Brazil Current is present along the slope year-round and water temperature varies little. Colder water demersal-benthonic slope species were more affected, probably moving southward or to deeper waters in the warm season when the Convergence is further south. With increasing depth, the demersal-benthonic bony fishes that move northward are more abundant in winter, while no seasonal fluctuation was observed for the demersal-pelagic fauna, which was more abundant on the outer shelf compared to offshore. This situation is probably caused by the stronger convergence shift phenomena near the bottom than the surface, as the Brazil Current runs southward all year in the upper layers (Fig. 2).

Depth as the main ordination factor of marine fish assemblages is well documented (Lleonart \& Roel 1984, Longhurst \& Pauly 1987, Bianchi 1991, 1992). Physical characteristics of the water masses (temperature, oxygen, salinity) as well as other factors such as bottom type, light intensity, and pressure are mostly related to depth (Bianchi 1991, 1992), but the way in which these factors affect the fish distribution pattern, and the intensity of their effects, are difficult to assess and our data do not support further analysis.

Catches and species numbers in the 2 southern cruises were compared with catches in 2 surveys on the inner shelf between 10 and $120 \mathrm{~m}$ in the same seasons in April 1983 and August 1983 (unpubl. data). Catches from the shelf were divided by 2 as the net used on the shelf had a footrope of $52.9 \mathrm{~m}$, approximately twice the length of the one in the present study (Fig. 5). In winter greater catches were observed on the shelf between 40 and $60 \mathrm{~m}$, in the core of the inner branch of the Malvinas/Falkland Current. Demersalpelagic species were more abundant and therefore associated with the higher winter pelagic productivity. A second, much smaller, peak was found on the upper slope between 250 and $350 \mathrm{~m}$, mostly composed of Polyprion americanus and Ariomma bondi. The highest mean number of species per trawl was found in the shelf break and included both resident and northward winter immigrant species of the shelf and slope. In summer, the shelf peak was lower, in the 20 to $60 \mathrm{~m}$ depth range, and a there was a shelf break peak composed mainly of Trichiurus lepturus and Trachurus lathami. This shelf break peak is probably associated with the vortices and the partial upwelling of subtropical waters (Podesta 1990, Lima 1992). Many of the demersal-pelagic species of wide geographic distribution represented by adults in the survey were sexually mature. Egg and larval survival of these species may be favored by the upwelling and transport from the slope to more productive waters of the shelf, as suggested for Maurolicus muelleri by Weiss et al. (1988).

Despite the lower catches compared to the inner shelf, the number of species was high on the shelf break (Fig. 5). This may be due to a higher variety of soft and consolidated substrates and the overlapping of different water masses along the water column. A sharp decrease in the number of species was observed at depths greater than $350 \mathrm{~m}$ and may be associated with the generally poor benthic invertebrate fauna of the slope found by Capitoli \& Bonilha (1991).

Catches of demersal-pelagic species under the core of the Brazil Current in the upper slope were very low 
Fig. 5. Relative abundance $(\mathrm{kg}$ $\left.\mathrm{h}^{-1}\right)$ and number of teleost spe. cies per depth range in the cold and warm season cruises off southern Brazil (see text for details)
Winter-spring cruises

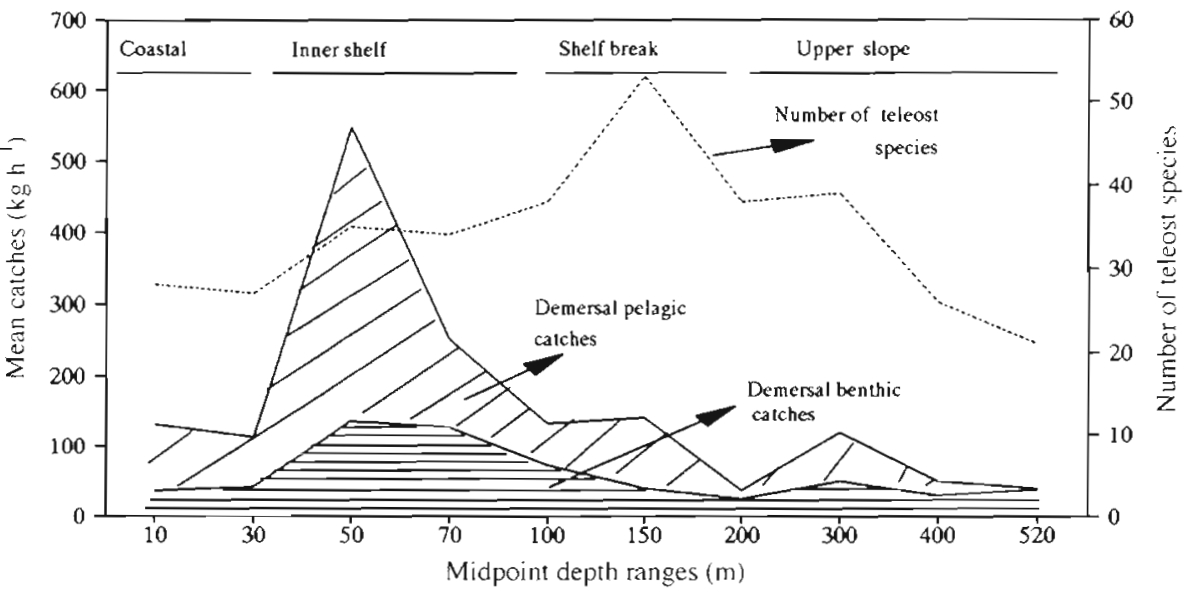

Summer-autumn cruises

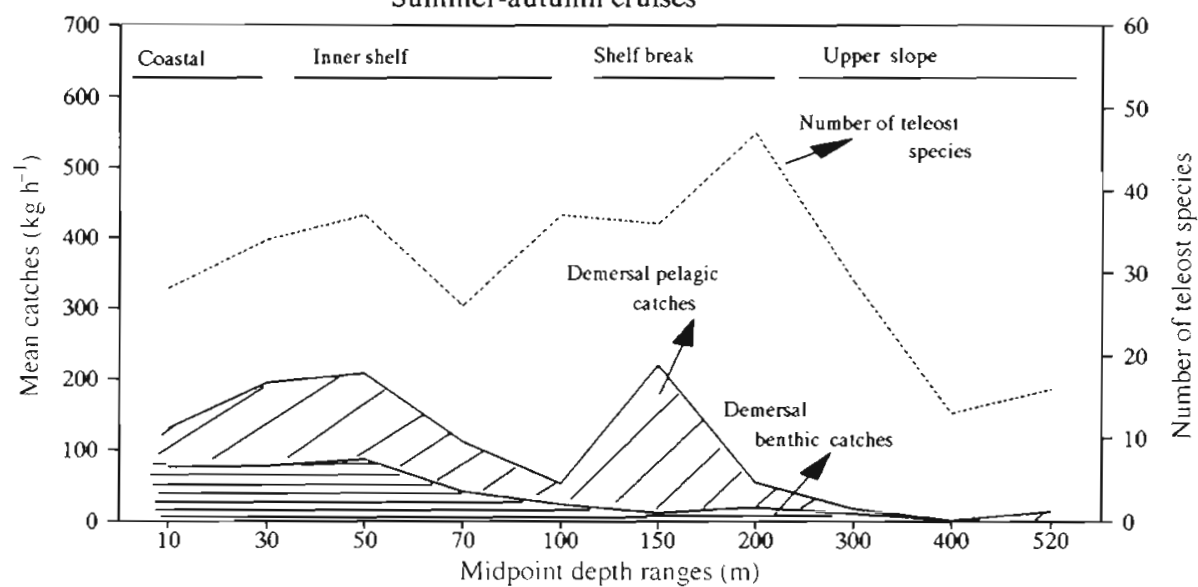

and, at least in winter and spring, the short fin squid Illex argentinus was rather abundant (Haimovici \& Perez 1991a). Ommastrephid squids may be an important part of the demersal-pelagic necton of the upper slope. Amaratunga (1983) and Santos (1992) showed the importance of $I$. argentinus in the food chains of that region.

The only bottom fish resources of the shelf break and upper slope are the migratory school shark Galeorhinus galeus in winter and Polyprion americanus (Vooren et al. 1988), both more efficiently fished with bottom longline, the king crab Chaceon notialis (syn. Geryon quinquedens) (Lima \& Lima 1991) and the short fin squid Illex argentinus (Haimovici \& Perez 1991a). Bony fish from the shelf break and upper slope do not appear to sustain a large commercial bottom trawl fishery but the catches of demersal-pelagic small bony fish, e.g. Ariomma bondi, Trachurus lathami, Scomber japonicus, and Trichiurus lepturus, all feeding mainly on zooplankton, were considerable in some hauls. Their midwater trawl-fishing potential is still unknown.
Acknowledgements. The authors thank C. Borzone for his help with the multivariate analysis and J. P. Castello for his comments on the hydrographic description. B. A. G. Lourerio drew the figures. The research was funded by the Banco do Brasil Research Fund (FIPEC) and grants to M.H. from the Brazilian Research Council (CNPq).

\section{LITERATURE CITED}

Amaratunga, I (1983). The role of Cephalopoda in the marine ecosystem. In: Caddy, J. F. (ed.) Advances in assessment of world cephalopod resources. FAO Fish. tech. Pap. 231: 379-415

Angelescu, V., Prenski, L. B. (1987). Ecología trófica de la merluza común del Mar Argentino (Merlucciidae, Merluccius merluccius hubbsi), Parte 2. Série Contribuciones No. 561. INIDEP, Mar del Plata

Benvegnú-Lé, G. Q. (1978). Distribuiçāo dos peixes teleósteos marinhos demersais na plataforma continental do Rio Grande do Sul. Ph.D. thesis, Universidade de São Paulo

Bianchi, G. (1991). Demersal assemblages of the continental shelf and slope edge between the Gulf of Tehuantepec (Mexico) and Gulf of Papagayo (Costa Rica). Mar. Ecol. Prog. Ser. 73: 121-140 
Bianchi, G. (1992). Study of the demersal assemblages of the continental shelf and upper slope off Congo and Gabon, based on the trawl surveys of the RV 'Dr Fridtjof Nansen' Mar. Ecol. Prog. Ser. 85: 9-23

Capitoli, R., Bonilha, L. E. (1991). Comunidades bentônicas In: Vooren, C. M. (ed.) Projeto Talude. FIPEC Final Report, FURG, Rio Grande, p. 79-92

Capitoli, R., Haimovici, M. (1993). Dieta alimenticia del besugo Pagrus pagrus en el extremo sur de Brasil. Frente Maritimo, Montevideo 14: 81-86

Castello, J. P. (1991). Hidrografia. In: Vooren, C. M. (ed.) Projeto Talude. FIPEC Final Report, FURG, Rio Grande, p. $19-22$

Castello, J. P., Moller, O. Jr (1977). Sobre as condiçōes oceanográficas do Rio Grande do Sul. Atlântica, Rio Grande 2(2): 1-19

Cohen, D. M., Inada, T., Iwamoto, T., Scialabba, N. (1990). FAO Species Catalogue Vol. 10, Gadiform fishes of the world (Order Gadiformes). FAO Fish. Synopsis 125, Rome

D'Incao, F., Ruffino, M. L. (1991). Crustáceos Decapoda e Stomatopoda. In: Vooren, C. M. (ed.) Projeto Talude. FIPEC Final Report, FURG, Rio Grande, p. 67-78

Emilsson, 1. (1961). The shelf and coastal waters off southern Brasil. Bolm Inst. Oceanogr. S. Paulo 11(2): 101-112

Fagundes Neto, E. B., Gaelzer, E. L. R. (1991). Associaçōes de peixes bentônicos e demersais na regiāo do Cabo Frio, RJ Brasil. Nerítica 6(1-2): 139-156

Fernandez, A., Norbis, W. (1986). Distribucion y abundancia de la castañeta (Cheilodactylus bergi) en la Zona Comun de Pesca Argentino Uruguaya durante el periodo 1980-1984. Publnes Comn téc. mixt. Frente marit., Montevideo 1(1): $180-190$

Figueiredo, J. L. (1981). Estudo das distribuições endêmicas de peixes da Província Zoogeográfica Marinha Argentina. Ph.D. thesis, Universidade de São Paulo

Figueiredo, J. L. (1992). Sobre a aplicaçāo dos nomes Cynoscion striatus (Cuvier, 1829) e Cynoscion guatucupa (Cuvier, 1830) (Teleostei: Sciaenidae). Comun. Mus. Ciên. PUC RS, sér. zool, Porto Alegre 5(8): 117-121

Figueiredo, J. L., Menezes, N. A. (1978). Manual de peixes marinhos do sudeste do Brasil. II. Teleostei (1). Museu de Zoologia da Universidade de Sào Paulo, São Paulo

Figueiredo, J. L., Menezes, N. A. (1980). Manual de peixes marinhos do sudeste do Brasil. III. Teleostei (2). Museu de Zoologia da Universidade de São Paulo, São Paulo

Fischer, W. (ed.) (1978). FAO species identification sheets for fishery purposes. Western Central Atlantic (fishing area 31), Vols 1-7. FAO, Rome

Gauch, H. G. (1982). Multivariate analysis in community ecology. Cambridge University Press, Cambridge

Haimovici, M. (1982). Estructura y dinamica poblacional del pargo blanco Umbrina canosai (Pisces, Sciaenidae) del litoral de Rio Grande do Sul, Brasil. Ph.D. thesis, Universidade de Buenos Aires

Haimovici, M. (1991). Edad, crecimiento y tipos de escamas del besugo (Pagrus pagrus) en el sur de Brasil. Octavo Simposio Cientifico de la Com. Tec. Mix. del Frente Maritimo. 2 a 4 de Diciembre de 1991, Abstracts. Montevideo, p. 41

Haimovici, M., Arruda, M. C., Teixeira, R. L. (1989a). Alimentação da castanha Umbrina canosai no litoral sul de Brasil. Rev. Bras. Biol 49(2): 511-522

Haimovici, M., Cousin, J. C. B. (1989). Reproductive biology of the castanha Umbrina canosai (Pisces, Sciaenidae) in southern Brazil. Rev. Bras. Biol. 49(2): 523-537

Haimovici, M., Martins, A. S., Teixeira, R. L. (1993). Distribuición, alimentación y observaciones sobre la reproduc- cion de la merluza Merluccius hubbsi en el sur de Brasil Frente Maritimo, Montevideo 14: 33-40

Haimovici, M., Pereira, S. D., Vieira, P. C. (1989b). La pesca demersal en el sur de Brasil en el período 1975-1985 Frente Maritimo, Montevideo 5: 151-163

Haimovici, M., Perez, J. A. A. (1991a). A pesca de cefalópodes em quatro cruzeiros de prospeção pesqueira demersal na plataforma externa e tâlude continental do sul do Brasil entre Chuí $\left(34^{\circ} 30^{\prime}\right.$ S) e o Cabo de Santa Marta Grande ( $28^{\circ} 40^{\prime}$ S). Atlântica, Rio Grande 13(1): 189-200

Haimovici, M., Perez, J. A. A. (1991b). A coastal cephalopod fauna of southern Brazil. Bull. mar. Sci. 49(1-2): 221-230

Haimovici, M., Reis, E. G. (1984). Determinação de idade e crescimento da castanha Umbrina canosai (Pisces, Sciaenidae) do sul do Brasil. Atlântica, Rio Grande 7: 25-46

Hubold, G. (1980a). Hydrography and plankton off southern Brazil and Rio de La Plata, August-November, 1977. Atlântica, Rio Grande 4(1): 1-22

Hubold, G. (1980b). Second report on hydrography and plankton off southern Brazil and Rio de la Plata; autumn cruise: April-June 1978. Atlantica, Rio Grande 4: 23-42

Hulley, P. A. (1981). Results of the research cruises of FRV 'Walther Herwig' to South America. LVIII. Family Myctophidae (Osteichthyes, Myctophiformes). Arch. FischWiss. 31(1): $1-300$

Legekis, R., Gordon, A. (1982). Satellite observations of the Brazil and Falkland currents, 1975 to 1976 . Deep Sea Res. 29(3A): $375-401$

Lima, I. D. Jr (1992). Distribuiçāo e abundância de anchoita Engraulis anchoita em relação aos processos oceanográficos na plataforma continental do sul do Brasil. M.Sc. thesis, Universidade do Rio Grande

Lima, J. H. M., Lima, B. R. (1991). Análise das operações de pesca do caranguejo de profundidade Geryon quinquedens Smith 1879, por barcos japoneses arrendados na região sul do Brasil - 1984/85. Atlântica, Rio Grande 13(1): 179-188

Lleonart, J., Roel, B. (1984). Análisis de las comunidades de peces y crustáceos demersales de la costa de Namibia (Atlántico Sudoriental). Invest. pesq. 48(2): 187-206

Longhurst, A. R., Pauly, D. (1987). Ecology of tropical oceans. Academic Press, San Diego

Macpherson, E. (1983). Ecologia trófica de peces en las costas de Namibia. I. Hábitos alimentarios. Invest. pesq. 11: $81-137$

Manooch, C. S., Hassler, W. W. (1978). Synopsis of the biological data on the red porgy Pagrus pagrus (Linnaeus). NOAA Tech. Rep. NMFS Circular 412. FAO Fish. Synopsis 116

Martins, A. S. (1992). Bioecologia do peixe-espada Trichiurus lepturus Linnaeus, 1758, no sul do Brasil. M.Sc. thesis, Universidade do Rio Grande

Martins, L. R., Urien, C. M., Butler, L. W., Martins, I. R. (1975). Morfologia e sedimentos da plataforma continental atlàntica sulamericana entre o cabo Orange e o Chuí (Brasil). Anais Hidrográficos 3-32, p. 81-106

Matsuura, Y (1986). Contribuiçāo ao estudo da estrutura oceanográfica da região entre Cabo Frio (RJ) e o Cabo de Santa Marta Grande (SC). Ciênc. Cult. (Sao Paulo) 38(8): $1439-1450$

Menezes, N. A., Figueiredo, J. L. (1980). Manual de peixes marinhos do sudeste do Brasil. IV. Teleostei (3). Museu de Zoologia da Universidade de São Paulo, São Paulo

Menezes, N. A., Figueiredo, J. L. (1985). Manual de peixes marinhos do sudeste do Brasil. V. Teleostei (4). Museu de Zoologia da Universidade de São Paulo, São Paulo

Menni, R. C., Ringuelet, R. A., Aramburu, R. H. (1984). Peces marinos de la Argentina y Uruguay. Editorial Hemisferio Sur, Buenos Aires 
Migliore, M. M. (1988). Biologia y parametros poblacionales del rubio (Helicolenus dactylopterus lahillei Norman, 1937) Seminario de Investigacion, Univ. Nac. de Mar del Plata

Miranda, L. B, Leudemann, E. F., Miyao, S. Y (1973). Relatório sobre a segunda pesquisa oceanográfica e pesqueira do Atlântico Sul entre Torres e Maldonado (Lat. 29-35). Distribuição de temperatura, salinidade e circulação geral em superfície. Publ. esp. Inst. oceanogr. S Paulo 3(2): 1-82

Nakamura, I., Parin, N. V (1993). FAO Species Catalogue, Vol. 15, Snake mackerels and cutlassfishes of the world (Families Empylidae and Trichiuridae). FAO Fish. Synopsis 125

Nelson, J. S. (1984). Fishes of the world. John Wiley \& Sons, New York

Olson, D. B., Podesta, G. P., Evans, R. H., Brown, O. B. (1988), Temporal variation in the separation of the Brazil and Malvinas currents. Deep Sea Res. 35: 1971-1990

Otero, H., Bezzi, S., Renzi, M., Verazay, G. (1982). Atlas de los recursos pesqueros demersales del mar argentino. Contrib. 423 INIDEP, Mar del Plata

Palacio, J. F. (1982). Revisión zoogeográfica marina del sur del Brasil. Bolm Inst. Oceanogr. S. Paulo 31(1): 69-92

Perrota, R. G., Aubone, A., Sanchez, A. (1990). Estudio comparado de los caractéres morfométricos y merísticos de la caballa (Scomber japonicus Houttuyn, 1782) (Teleostei. Scombridae) del sur de Brasil y del área marplatense (Mar Argentino). Scientia mar. Barcelona 54(1): 47-53

Podesta, G. P. (1990). Migratory pattern of Argentine hake Merluccius hubbsi and oceanic processes in the Southwestern Atlantic Ocean. Fish. Bull. U.S. 88: 167-177

Roux, C. (1973). Résultats scientifiques des campagnes de la 'Calypso' large des côtes atlantiques de l'Amérique du Sud (1961-1962). Fascicule X. Campagne de la Calypso. Première partie (suite). 26. Poissons téléostéens du plateau continental brésilien. Masson et Cie, Paris

Santos, R. A. (1992). Relaçōes tróficas do calamar argentino Illex argentinus (Castellanos, 1960) (Teuthoidea: Ommastrephidae), no sul do Brasil. M.Sc. thesis, Universidade do Rio Grande

Schwingel, P. R. (1991). Alimentaçāo de Engraulis anchoita (Clupeiformes, en Engraulidade) na plataforma continental do Rio Grande do Sul, Brasil. M.Sc thesis, Universidade do Rio Grande

This article was submitted to the editor
Seckendorff, R. N., Zavala-Camin, L. A. (1985). Reprodução, crescimento e distribuição de Scomber japonicus. Bolm Inst. Pesca, S. Paulo 12(2): 1-13

Thomsen, H. (1962). Massas de agua caracteristicas del Oceano Atlântico (parte sudoeste). Secretaria de Marina/SHN, Buenos Aires, Publ. H623: 1-27

Vazzoler, G. (1975). Distribuição da fauna de peixes demersais e ecologia dos Sciaenidae da plataforma continental brasileira entre as latitudes $29^{\circ} 21^{\prime} \mathrm{S}$ (Torres) e $34^{\circ} 44^{\prime} \mathrm{S}$ (Chui). Bolm Inst. Oceanogr. S. Paulo 24: 85-169

Vieira, P. J. C. (1990). Biologia populacional de Cynoscion striatus (Pisces: Scianidae) no litoral sul do Brasil. M.Sc thesis, Universidade do Rio Grande

Vooren, C. M. (1991). Elasmobrânquios. In: Vooren, C. M. (ed.) 'Projeto Talude', Relatório Final. Convênio FIPECFURG, Rio Grande, p. 33-36

Vooren, C. M., Haimovici, M., Vieira, P. C., Duarte, V. S., Ferreira, B. P. (1988). Pesca experimental na margem externa da plataforma e no talude continental do Rio Grande no inverno de 1986. Anais do V Congresso Brasileiro de Engenharia de Pesca 435-447, Fortaleza

Wahlrich, R., Peres, M. B. (1990). Relatório final do projeto otimizaçào bioeconômica dos recursos pesqueiros marinhos do Rio Grande do Sul FA.PERGS. Universidade do Rio Grande, Rio Grande

Weiss, G., Hubold, G., Bonecker, A. C. T (1988). Eggs and larvae of Maurolicus muelleri (Gmelin, 1789) (Teleostei, Sternoptychidae) in the southwest Atlantic. Meeresforsch. 32(1): 53-60

Weitzman, S. H. (1986). Family no. 75: Sternoptychidae. In: Smith, M. Heemstra, P. C. (eds.) Smith's sea fishes. Springer-Verlag. Berlin, p. 253-259

Yesaki, M. (1973). Sumário dos levantamentos de pesca exploratória ao largo da costa sul do Brasil e estimativa da biomassa de peixe demersal e potencial pesqueiro. Doc. Tec. SUDEPE-PDP/T, Rio de Janeiro 1: 1-27

Yesaki, M., Barcellos, B. N. (1974). Desenvolvimento da pesca do pargo róseo ao longo da costa sul do Brasil. Série Documentos Ocasionais SUDEPE-PDP, Rio de Janeiro 6 $1-8$

Yesaki, M., Rahn, E., Silva, G. (1976). Sumário das exploraçôes de peixes de arrasto de fundo ao largo da costa sul do Brasil. Doc. Tec. SUDEPE-PDP, Rio de Janeiro 19: $1-37$

Manuscript first received: October 15, 1993

Revised version accepted: February 2, 1994 